ROGELIO RUIZ GOMAR

INSTITUTO DE INVESTIGACIONES ESTÉTICAS, UNAM

\title{
Nuevas noticias sobre los Ramírez, artistas novohispanos del siglo XVII
}

a Efraín Castro M orales

[ I trabajo que dedicó Efraín Castro M orales a los "Ramírez", importantes artistas que se desenvolvieron en la N ueva España a lo largo del siglo XVII, vino a significar un positivo avance 0 , mejor aún, un auténtico parteaguas en el estudio de los miembros de esa familia - tanto a nivel global como particular - , por la cantidad e importancia de las noticias en él contenidas. ${ }^{\text {I }}$ D icho trabajo no sólo fue la ocasión que le permitió sacar a la luz novedosa información, fruto de sus acuciosas y largas sesiones en distintos archivos, sino también la oportunidad de reunir y poner orden en las dispersas noticias que se tenían de la vida y actuación de todos y cada uno de los miembros de dicha familia. Y si bien uno de los logros más significativos de ese estudio fue el de lograr establecer el confuso o ignorado vínculo familiar que existía entre ellos - como, por ejemplo, el que el pintor Pedro Ramírez y el conocido ensamblador Laureano Ramírez de Contreras resultaran ser hermanos- , la más valiosa aportación del trabajo fue, a mi juicio, la de

I. Efraín Castro M orales, "Los Ramírez, una familia de artistas novohispanos del siglo XVII", en Boletín de M onumentos $\mathrm{H}$ istóricos, núm. 8, M éxico, Instituto $\mathrm{N}$ acional de Antropología e H istoria, 1982. 
DOI: http://dx.doi.org/10.22201/iie.18703062e.2000.77.1948

68

ROGELIO RUIZ GOMAR

que por fin se puso en claro que bajo el nombre de Pedro Ramírez se escondían, en realidad, dos artífices diferentes, de campos profesionales distintos, padre e hijo, respectivamente. El que padre e hijo compartieran el mismo nombre y el que ambos, curiosamente, murieran con una diferencia de meses en el mismo año de i679 fueron sin duda factores que contribuyeron a acentuar la confusión en que hasta ese momento todos estábamos sumidos. ${ }^{2}$ Precisados ya los perfiles biográficos de cada uno, habrá que empezar a llamarles el viejo y el joven para diferenciarlos entre sí, o incorporarle al segundo el apellido materno de Contreras que a diferencia de su hermano Laureano él nunca usó.

Gracias a dicho trabajo sabemos, pues, que la presencia en la N ueva España de esta familia comienza con el maestro ensamblador de origen sevillano D iego Ramírez, a quien sucede su hijo, el maestro escultor, entallador y arquitecto, también nacido en Sevilla, Pedro Ramírez el viejo, padre a su vez de varios hijos, entre los que están Pedro Ramírez el joven, o el mozo, maestro en el arte de la pintura, y de Laureano Ramírez de Contreras, el último maestro ensamblador y entallador de la dinastía, amén de José Ramírez, acuñador en la C asa de M oneda y de dos clérigos, todos ellos ya nacidos en la ciudad de M éxico.

Con ser tan abundante en información el esclarecedor trabajo del doctor Castro, quiero agregar algunas noticias que he reunido en torno a los miembros de esta importante familia, las cuales se desprenden de una revisión aún incompleta que pude llevar a cabo en el rico Archivo del Sagrario de la C atedral de M éxico. ${ }^{3}$ En unos casos, tales noticias vienen simplemente a corroborar 0 a completar lo ya apuntado por Castro M orales, utilizando diferentes fuentes; pero en otros vienen a aportar nueva luz que permitirá llenar algunas de las lagunas que aún nos quedan sobre sus personas, afinar los lazos de las relaciones dadas en el seno mismo de la familia y conocer mejor los víncu-

2. C abe señalar, en justicia, que desde i965, en que apareció el libro Pintura colonial en M é xico de $M$ anuel T oussaint, ya Xavier M oyssén había manifestado que se trataba de dos artistas diferentes - aunque sin reparar en que eran parientes - , basándose para ello en las referencias documentales reunidas por $\mathrm{H}$ einrich Berlin en el Archivo General de la $\mathrm{N}$ ación; véase la nota is que puso al capítulo XVII de dicha obra, M éxico, U niversidad N acional Autónoma de M éxico, Instituto de I nvestigaciones Estéticas, p. 257.

3. Agradezco las facilidades que recibí para su consulta por parte del párroco del Sagrario, Rubén Ávila Enríquez - actual canónigo deán de la C atedral de M éxico- , y del señor Ricardo G racida, administrador del mismo. 
DOI: http://dx.doi.org/10.22201/iie.18703062e.2000.77.1948

NUEVAS NOTICIAS SOBRE LOS RAMÍREZ

los que los integrantes de la misma fueron tejiendo con distintos miembros de la sociedad colonial de su tiempo. Tal es el propósito de este trabajo.

\section{D iego Ramírez}

El primero de la familia en arribar a la N ueva España y avecindarse en ella fue D iego Ramírez, quien a principios del siglo XvII llegó procedente de Sevilla, en compañía de su esposa, Inés de la Cruz, y de sus tres hijos: Ú rsula de la Cruz, M elchora de los Reyes y Pedro Ramírez. Y si bien no se ha podido de terminar la fecha en que se estableció en la ciudad de M éxico, se puede suponer que ello ocurrió hacia la segunda década de esa centuria. Con buen juicio, Efraín C astro propone que identifiquemos a este personaje con el maestro ensamblador y entallador de ese nombre, que aparece realizando diversos e importantes trabajos en el medio novohispano del primer tercio del siglo XVII. ${ }^{4}$ Pero de lo que sí estamos seguros es de que ya en la ciudad de M éxico, y tras enviudar, contrajo segundas nupcias en mayo de 1626 con I sabel de Ábrego, natural de esta ciudad de M éxico. 5 Como fruto de este segundo matrimonio, de acuerdo con los registros parroquiales de la catedral, nacieron cuatro hijas más: Josefa (Josepha) (I629), Catalina (I630), Damiana (I633) y Francisca (1636), ${ }^{6}$ las cuales habrían de nacer prácticamente por los mismos años que sus nietos, procreados también en M éxico por los hijos del primer matrimonio.

4. Vid. Efraín Castro, op. cit., pp. 8-9.

5. Ella era hija de Juan D elgado e Inés de Ábrego. Archivo del Sagrario M etropolitano (en adelante ASM ), Libro 2 de amonestaciones de españoles, I624-I628, f. 21 .

6. La partida de bautismo de J osefa (is de marzo de i629) - de quien fueron padrinos D iego López M orillo y Francisca de Figueroa - se encuentra en ASM , Libro II de bautismos de es pañoles, I627-I629, f. I94V; las de Catalina (25 de abril de I630) y D amiana (I2 de octubre de I633) en ASM, Libro I2 de bautismos de españoles, I629-I634, fs. 47 y 315; y la de Francisca (27 de abril de ${ }_{1} 636$, de quien fueron padrinos su medio hermano Pedro Ramírez y su esposa) en ASM , Libro I3 de bautismos de españoles, I634-I639, f. I27. Esta última debe ser la Francisca Ramírez que casa con José de Castro, en agosto de ${ }_{1663}$ (ASM , Libro 8 de matrimonios de españoles, I657-I667, f. I80); ceremonia en que encontraremos a sus sobrinos Juan (vid. infra nota 29), Agustín (vid. infra nota 35) y Laureano Ramírez (vid. infra nota 98), los dos primeros ya como sacerdotes; el primero ofició en la ceremonia y los otros dos fungieron como testigos. EI D iego López M orillo citado como padrino de J osefa era un maestro "de carpintería de lozas y cubiertas de iglesias", véase Efraín Castro M orales, "El Santuario de Guadalupe en el siglo xVII", en Retablo barroco a la memoria de Francisco de la M aza, M éxico, un AM, I974, p. 72. 
DOI: http://dx.doi.org/10.22201/iie.18703062e.2000.77.1948

70

ROGELIO RUIZ GOMAR

De los dichos hijos del primer matrimonio, nacidos en Sevilla, puedo agregar que Ú rsula de la Cruz casó en mayo de i632, en M éxico, con Andrés de Alonso, natural de Castilla. ${ }^{7}$ Q ue un año más tarde M elchora de los Reyes hizo lo propio con G erónimo de Avilés (mayo de 1633 ), ${ }^{8}$ matrimonio del que nacieron tres hijos: M ariana (1636), Antonio (I644) y José (I650). La primera y el último fueron llevados a la pila bautismal por su tío Pedro Ramírez (io de agosto de 1636 y 26 de noviembre de I650), 9 en tanto que el segundo fue apadrinado por el matrimonio formado por el conocido y excelente pintor José Juárez e I sabel de Contreras (25 de abril de i644)..'

Resulta difícil establecer la fecha de muerte de Diego Ramírez, pero podemos suponer que debió de ocurrir hacia finales de la cuarta década del siglo XVII, pues en i636 nació su última hija Francisca y en septiembre de i638 parece fungir como padrino de su nieto Pedro Ramírez, el mozo.

\section{Pedro Ramírez, el viejo}

D e Pedro Ramírez, el viejo, sabíamos, gracias a Efraín Castro, que había "nacido en la ciudad de Sevilla" y que, en I634, ya vecino de la de M éxico, se había casado con I sabel de Contreras. ".I Ahora puedo precisar que ese matrimonio se verificó a finales de octubre de $\mathrm{I}_{6} 3{ }_{4}{ }^{\mathrm{I2}}$ y que su esposa, originaria de esta ciudad de M éxico, había nacido a principios de ı6ı4, dentro del matrimonio formado por Pedro de Palencia e Isabel de Contreras. ${ }^{13}$

0 cho fueron los hijos de Pedro Ramírez, el viejo - al menos los que llevó

7. Él era hijo de Alonso M atheo y Francisca Yllana. Fueron testigos del enlace Diego y Pedro Ramírez, padre y hermano de la contrayente. ASM , Libro 3 de amonestaciones de españoles, I629-I634, f. 53, y Libro s de matrimonios de españoles, I629-I637, f. $39 \mathrm{~V}$.

8. Éste era viudo de M aría de Pantoja. ASM , Libro 3 deamonestaciones de españoles, $1629-1634$, f. 68 .

9. ASM , Libro I3 de bautismos de españoles, I634-I639, f. I54V, y ASM, Libro I6 de bautismos de españoles, I647-I652, f. 24I.

Io. ASM, Libro Is de bautismos de españoles, I644-I647, f. $24 \mathrm{~V}$.

II. Efraín Castro, op. cit., p. 9.

I2. ASM, Libro 4 de amonestaciones de españoles, I634-I640, f. 6.

I3. ASM, Libro 8 de bautismos de españoles, f. 82v. Pese a tener el mismo nombre y apellido, esta mujer no parece tener ningún lazo de parentesco con la I sabel de Contreras que hemos encontrado apadrinando, junto con su esposo el afamado pintor José Juárez, al niño Antonio, pues esta última era hija de Pedro López de C ontreras y J erónima G utiérrez; vid supra nota io. 
DOI: http://dx.doi.org/10.22201/iie.18703062e.2000.77.1948

NUEVAS NOTICIAS SOBRE LOS RAMÍREZ

a bautizar a la parroquia de la catedral- : Juan (I636), Josepha (Josefa) (I637), Pedro (I638), Laureano (I640), los gemelos Agustín y Agustina (I642), $M$ athias (I646) y Joseph (1650).14

O tras noticias referentes a Pedro Ramírez, el viejo, en el archivo parroquial de la catedral son las de que fungió como testigo en la boda de su hermana Ú rsula, en I632,15 que fue padrino de bautizo de Francisca, su media hermana, última hija del segundo matrimonio de su padre, en abril de I636, ${ }^{16}$ así como de M ariana (agosto de ${ }_{1636}$ ) y de José (noviembre de I650), dos de los hijos de su hermana M elchora. ${ }^{17} \mathrm{Q}$ ue en el año de 1646 apadrinó, también, a Josefa, una hija del matrimonio formado por Francisco Becerra y M aría de Alba (i8 de abril), y a D iego, hijo de Agustín Gómez de Prado y Te resa de C ontreras (23 de octubre). ${ }^{18} \mathrm{Q}$ ue fue padrino de bautizo, igualmente, de una niña expuesta, ${ }^{19}$ así como de una hija del pintor Sebastián López D ávalos y su esposa, M aría de M edina Calderón, el 8 de marzo de $1655,{ }^{20}$ y en I668 lo sería de su nieta M aría Teresa, niña procreada por su hijo Laureano. ${ }^{2 I}$

Por lo vago de la referencia no es posible afirmar si el Pedro Ramírez que aparece en febrero de i650 como testigo en el enlace de Cristóbal de Porras

I4. Las partidas de bautizo de Juan (I7 de febrero de I636) y Josefa (3 de mayo de I637) están en ASM, Libro $I_{3}$ de bautismos de españoles, I634-I639, fS. IO7 Y $222 \mathrm{~V}$; de Juan fueron padrinos Francisco Canalejo y M argarita de Covarrubias, y ofició el doctor $M$ iguel de Poblete; de Josefa fueron padrinos el capitán Francisco Escoto (Scoto) (acaso el que años más tarde, en ı648, aparece como el "factor del puerto de Acapulco") y doña Juana de Covarrubias. Las partidas de bautizo de Pedro y Laureano las veremos más adelante. Las de Agustín y Agustina ( 6 de septiembre de I642), de quienes fue madrina doña I sabel de Contreras, su abuela materna, están en ASM, Libro I4 de bautismos de españoles, I640-I643, f. 2IIV. La de M athias ( 2 de marzo de 1646 ), de quien fue padrino Juan Lozano de Balbuena, en ASM , Libro is de bautismos de españoles, I644-I647, f. I72V, y la de J oseph (I4 de agosto de I650), de quien fue madrina nuevamente doña J uana de Covarrubias, en ASM , Libro I6 de bautismos de españoles, I647I652, f. 219 .

15. Vid. supra nota 7.

I6. Vid. supra nota 6 (ASM, Libro I3 de bautismos de españoles, I634-I639, f. I27).

I7. Vid. supra nota 9 (ASM, Libro I3 de bautismos de españoles, I634-I639, f. I54V, y Libro I6 de bautismos de españoles, $1647-1652$, f. 24I).

I8. En el bautizo de este último lo acompañó como madrina la ya citada doña Juana de C ovarrubias. ASM, Libro Is de bautismos de españoles, fs. I84 y 226, respectivamente.

19. De Luisa, en noviembre de I649: ASM, Libro I6 de bautismos de españoles, I647-I652, f. $155 \mathrm{~V}$.

20. ASM , Libro ${ }_{17}$ de bautismos de españoles, $1652-1655$, f. $217 \mathrm{~V}$.

2I. ASM , Libro 22 de bautismos de españoles, I667-I669, f. II9. Vid. infra nota 83. 
DOI: http://dx.doi.org/10.22201/iie.18703062e.2000.77.1948

72

ROGELIO RUIZ GOMAR

con $\mathrm{N}$ icolasa de Aguilar es el artista que nos ocupa 0 al gún homónimo. ${ }^{22} \mathrm{D}$ el mismo modo, contamos con otras noticias en las que, por lo avanzado de las fechas, es imposible determinar si el Pedro Ramírez consignado es el padre 0 el hijo, o si también aquí es simplemente al guien del mismo nombre, ajeno a la familia. Ello ocurre con el Pedro Ramírez que el 30 de junio de i66o funge como padrino de bautizo de Bernabé, hijo de Pedro Sánchez Q uijada y Catarina de Rivera, ${ }^{23}$ así como de otros tres "hijos de la I glesia", como se les llamaba en la época a los niños abandonados o expósitos, uno en i667 y dos en I677. ${ }^{24}$ Lo mismo ocurre con el Pedro Ramírez que encontramos como testigo en dos matrimonios; en el primero figura en compañía de Laureano Ramírez como testigo en la boda de M athias de U ribe con doña Luisa de Vargas ( $\mathrm{I}^{\circ}$ de enero de i669); y en el segundo, junto con un Simón Ramírez, en la boda de $\mathrm{N}$ icolás de $\mathrm{O}$ rtega con M aría de Contreras (I8 de abril de 1672).25 Aceptando por ahora que no se trate de un homónimo - por más que, insisto, es difícil establecer si se trata del padre o el hijo- , tampoco se puede decir nada en relación a si en esos casos existía algún tipo de parentesco, o simplemente lazos de amistad o laborales entre ellos y alguno de los contrayentes.

22. Es necesario tener siempre en cuenta el problema de los homónimos con el fin de evitar confusiones y seguir pistas equivocadas. Para que se advierta cuán complejo puede ser el asunto, me parece suficiente mencionar aquí las noticias de al menos otros seis sujetos que respondían al mismo nombre y que habitaban en la ciudad de M éxico por esos mismos años: el Pe dro Ramírez de Leyba, natural de Córdoba, España, que se casa en julio de i628 con Francisca de la C ruz; el Pedro Ramírez esposo de I sabel de C astro - cuya hija M aría se casaba en i636 con Agustín Díaz- ; el Pedro Ramírez, originario igualmente de Sevilla y residente en M éxico desde ı646, que se casó con M aría Sánchez Villarroel; el Pedro Ramírez de O Ivera que se casó en septiembre de i647 con doña Clara de M edina; el Pedro Ramírez Anares de los Reyes, viudo de I sabel de V aldés, que se casó en r65 con doña Antonia de Frías; y el también sevillano Pedro Ramírez de Cañizares, que se casó en mayo de i666 con doña M aría Fernández de Castro.

23. ASM , Libro 20 de bautismos de españoles, I660-I663, f. 4.

24. D eAntonio, en marzo de i667: ASM , Libro 21 de bautismos de españoles, I663-I667, f. 322. (A caso éste es el Antonio Ramírez de Contreras, "huérfano" que en febrero de i689 se casaba con Antonia Gómez: ASM , Libro I3 de amonestaciones de españoles, I688-I694, f. 28); de Pedro de San M iguel, en mayo de i677, y de Agustina Rosa - expuesta en la casa de doña M aría de Albacar-, en septiembre del mismo año: ASM, Libro 25 de bautismos de españoles, I674-I679, fs. $233 \mathrm{~V}$ y $263 \mathrm{~V}$.

25. Las partidas correspondientes están en ASM, Libro 9 de matrimonios de españoles, 1667 I672, fS. 36V y I32V. En la primera de dichas bodas ofició otro hijo de Pedro Ramírez, el viejo: el bachiller Juan Ramírez. 
Aunque ya Efraín Castro proporcionó la fecha de su muerte, ocurrida el 29 de marzo de i679, quiero transcribir la partida de defunción correspondiente, por cuanto complementa datos por él consignados:

En 29 de marzo de [16]79 años, murió Pedro Ramírez, maestro de ensamblador. Testó ante Francisco de Q uiñones, escribano real, en 27 de agosto de 77; dejó por sus albaceas a sus hijos y al capitán Gabriel de la Cruz, escribano real. N 0 dejó misas. Enterróse en El Carmen. ${ }^{26}$

Por la repetición del apellido, acaso el tal capitán y escribano real, Gabriel de la Cruz, designado como albacea, resulte pariente de su madre. Sobre el sitio en que fue enterrado conviene recordar las noticias recogidas por Efraín C astro acerca de que Pedro Ramírez, padre, había sido síndico del Colegio de Carmelitas descalzos de Santa Ana, en la villa de Coyoacán (que hoy conocemos como El Carmen de San Ángel), y la de que, de acuerdo con una cláusula de su testa mento, había expresado su voluntad de ser enterrado en la iglesia del Convento de El Carmen - en el centro de la ciudad de M éxico- "en el altar de N uestra Señora de Guadalupe, donde tenía su entierro", sitio en el que más tarde habrían también de ser sepultados sus hijos Pedro, Laureano, A gustín y Juan.

$N$ oticia extrafamiliar, pero que conviene retener por cuanto nos deja saber la fama que le rodeaba en su tiempo, es la de que a principios de i675 murió doña Leonor de Amibilia, casada con José de Estupiñán, en cuya partida de defunción se asentó que vivía "en la esquina de Santa C atarina de Sena, en casas de Pedro Ramírez, de oficio de escultor". ${ }^{27}$

\section{N oticias de los hijos de Pedro Ramírez, el viejo}

Vayamos ahora a las noticias reunidas en el Archivo del Sagrario M etropolitano, en torno a sus hijos, con excepción de Pedro y Laureano, de quienes habremos de ocuparnos adelante con amplitud.

26. ASM, Libro $I$ de defunciones de españoles, I67I-I680, f. 292. En realidad, como asevera Castro M orales, designó por albaceas a su hijo Laureano y al mencionado capitán, y como herederos a todos sus hijos; op. cit., p. II.

27. El deceso fue el 4 de enero de i675, aunque por equivocación se puso el año de i674: ASM , Libro $I$ de defunciones, I67I-I680, f. IogV. 
DOI: http://dx.doi.org/10.22201/iie.18703062e.2000.77.1948

Por Efraín Castro sabíamos que Juan y Agustín habían seguido la carrera eclesiástica y "disfrutaban de las capellanías que fundara el padre, con gravámenes sobre las fincas de su propiedad" ${ }^{28} \mathrm{Al}$ primero, nacido en I636, lo encontramos oficiando en dos matrimonios: en el de su tía Francisca Ramírez - que era de su misma edad- con José de Castro, el ig de agosto de i663, y en el de M atías de U ribe con doña Luisa de Vargas, el I$^{0}$ de enero de 1669. ${ }^{29}$ Finalmente, lo encontramos a mediados de i680 como testigo en el matrimonio de su sobrino M iguel con N icolasa de San Pedro. ${ }^{30}$

El "licenciado Juan Ramírez" murió el 3 de diciembre de i68o. ${ }^{3}$ En la partida de defunción se asentó que testó ante Francisco de Q uiñones (is de noviembre de ese año), y que dejó por al baceas a sus hermanos Laureano y José Ramírez de Contreras; por su parte, Efraín Castro, que conoció dicho testamento, precisa que nombró por su heredero universal a L aureano. ${ }^{32}$

De Agustín Ramírez de Contreras ya hemos visto que nació - junto con su hermana Agustina - en i642, pues ambos fueron llevados a bautizar a la parroquia catedralicia en septiembre de ese año.33

No se vuelve a contar con noticias de él hasta agosto de i663, en que es consignado al lado de su hermano Laureano como testigo en la ya mencionada boda de José de C astro con Francisca Ramírez, ${ }^{34}$ enlace en el que ofició el otro hermano Juan, como acabamos de ver. ${ }^{35}$ Poco después se le registra como padrino de bautismo de su sobrina $\mathrm{N}$ icolasa (en septiembre de 1670 ), hija de Pedro Ramírez, el joven, y Josefa G ómez. ${ }^{36}$ I gnoramos cuándo se verificó su ordenación eclesiástica, pero para la segunda ceremonia contaba ya con 28 años, y es designado como "bachiller".

Años más tarde lo encontramos oficiando en el bautizo de M atiana Josefa, hija de su hermano Laureano ( 5 de marzo de I679),37 y en el del niño José

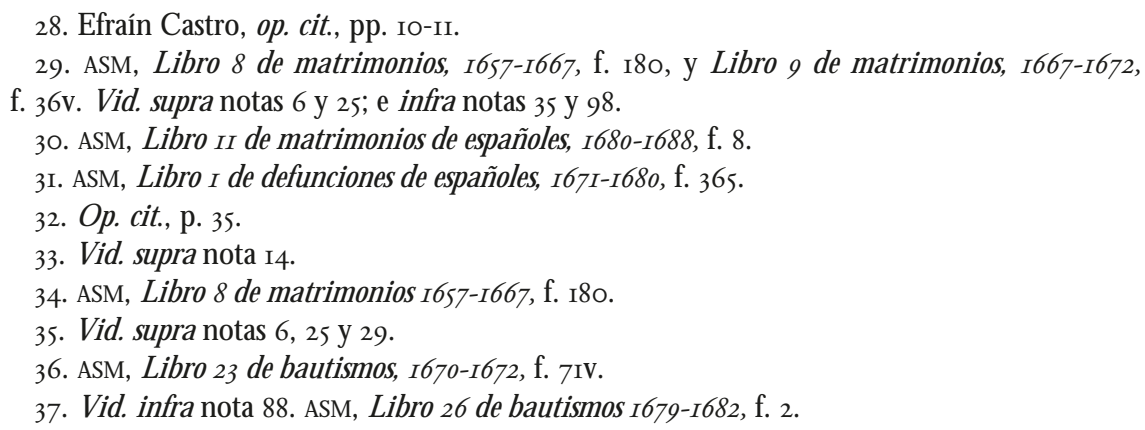


DOI: http://dx.doi.org/10.22201/iie.18703062e.2000.77.1948

NUEVAS NOTICIAS SOBRE LOS RAMÍREZ

Raimundo (ıo de septiembre de i682) - hijo del acaso pariente, bachiller Juan de Avilés Ramírez, médico, y de doña Antonia Sofía- , de quien fue padrino el propio Laureano..$^{38}$ Asimismo, bendijo la boda (el i8 de mayo de I687) de su sobrina N icolasa, la misma de quien había sido padrino de bautizo en I670, con Simón Fernández de Isla.39

Efraín Castro consigna que entre Agustín y Laureano surgieron algunas diferencias con relación al pago de la parte que les tocaba de la herencia dejada por su padre. ${ }^{\circ}$

El bachiller Agustín Ramírez de Contreras murió a los cincuenta años de edad, en i692. D el testamento que otorgó el 4 de septiembre de ese mismo año, Efraín Castro extrajo las siguientes noticias: que perteneció a la cofradía de San M iguel, en la iglesia del convento de La Encarnación, y a la hermandad de San Pedro, sita en la iglesia de La Santísima Trinidad, a la cual mandó entregar ornamentos e imágenes para adorno de su enfermería de sacerdotes; que dispuso ser enterrado en el sepulcro familiar en la iglesia de El Carmen, y que dejó por heredero universal al Colegio de Santa Ana, de carmelitas, en Coyoacán, del que, al igual que su padre, había sido síndico. ${ }^{41}$

Por lo que toca a José, quien fuera ensayador de la Real Casa de M oneda, sólo encontré en el Archivo del Sagrario, además de su partida de bautizo (I4

38. ASM , Libro 27 de bautismos $1682-1685$, f. 25V. Recuérdese que un tal Gerónimo de Avilés se había casado en i633 con M elchora, una de las hijas de D iego Ramírez (vid. supra nota 8).

39. ASM, Libro $I I$ de matrimonios I680-I688, f. 327V. Para lo referente al bautismo vid. supra nota 36; pero en lo tocante al matrimonio vid. infra notas 55 y 70.

40. D esde i679 Agustín se habría comprometido a que en año y medio no le pediría a Laureano lo que le correspondía ( 6567 pesos, 6 tomines y 9 granos), y que éste iría cubriendo esa cantidad con ciertos réditos. Como para febrero de i68 a aún le adeudaba cinco mil pesos, Laureano se comprometió a pagarle en tres años, quedando la casa que poséa en la calle del Reloj como garantía. Pero de nueva cuenta Laureano quedó sin cubrir la deuda y los réditos de las capellanías de que se beneficiaban J uan y Agustín, impuestas sobre las fincas que poseía y que, como hemos visto, habían sido fundadas por su padre. Por ello, en ese año de i68I, Agustín, como propietario que ya era de las dos capellanías - pues Juan había fallecido en ı680- , demandó a Laureano. Por auto del 22 de septiembre de ${ }_{1685}$ el juez visitador de testamentos, capellanías y obras pías del arzobispado decretó la excomunión de L aureano, por lo que su nombre, de acuerdo con la costumbre, fue inscrito en las tablillas de la catedral. Empero, cuatro días después, como apunta el doctor Castro M orales, Laureano fue absuelto, previo pago de lo que le debía al hermano. 0 p. cit., pp. 35-36. D e que la buena relación entre ellos se restableció da fe el hecho de que un año después Laureano designó a Agustín como al bacea en su testamento ( 23 de octubre de I686), vid. infra nota I07.

4I. Efraín Castro, op. cit., p. 36. 
DOI: http://dx.doi.org/10.22201/iie.18703062e.2000.77.1948

76

ROGELIO RUIZ GOMAR

de agosto de 1650 ), la noticia de que contrajo matrimonio a los 26 años - en julio de 1676 - con doña M aría M achado y Sierra. ${ }^{42}$ Por otro lado, aunque para entonces era menor de edad, creo que debe ser él quien figura el I4 de agosto de i672 como padrino de su sobrino Antonio, hijo de Pedro Ramírez, el mozo. ${ }^{43} \mathrm{D}$ el mismo modo, iserá éste el José Ramírez que aparece a finales de 1683 como testigo en la boda de José de O Imedo y M aría Teresa Ramírez, hija de Laureano?44 I gnoramos cuándo murió.

Finalmente, de los tres hijos restantes, Josefa, Agustina y M atías ( $M$ athias), cuyos bautizos hemos visto que se verificaron en los años de i637, ı642 y ı646, no afloró en el archivo consultado ninguna otra información, por lo que cabe suponer que murieron a temprana edad.

\section{Pedro Ramírez de Contreras, el joven}

Q uisiera detenerme ahora en los datos sobre la vida del segundo Pedro Ramírez, el pintor, puesto que, como indicó don M anuel Toussaint - señalamiento que era válido hasta hace poco- , "su biografía" era "puramente artística". 45

Un dato que de entrada se antoja necesario destacar es el de que nació en M éxico, como lo prueba fehacientemente su partida de bautismo, que localicé en la parroquia catedralicia y que permite constatar lo que Efraín C astro apenas sugirió: "Probablemente nació en la ciudad de M éxico... " Por el interés que encierra transcribo dicha partida:

En 23 de septiembre de [I]638 años, con licencia del cura [semanero], bauticé a Pedro, hijo de Pedro Ramírez e Isabel de Contreras; fueron sus padrinos D iego

42. Vecina de esta ciudad y viuda del capitán Pedro de Andrada. ASM , Libro II de amonestaciones de españoles, I670-I680, f. I42V. Al margen de la partida se advierte que el dicho José Ramírez debía "llevar certificación... para los señores curas de Santa Cathalina mártir", lo que permite inferir que al menos uno de los contrayentes era feligrés de esa parroquia.

43. Vid. infra nota 56 (ASM, Libro 24 de bautismos, $1672-1676$, f. 4).

44. Vid. infra notas 63 y 85.

45. M anuel Toussaint, Arte colonial en M éxico, M éxico, U niversidad N acional Autónoma de M éxico, Instituto de Investigaciones Estéticas, I962, p. II5. 
DOI: http://dx.doi.org/10.22201/iie.18703062e.2000.77.1948

NUEVAS NOTICIAS SOBRE LOS RAMÍREZ

Ramírez e I sabel de Contreras. Licenciado H ernando del Águila [rúbrica]. El Licenciado D iego Rangel [rúbrica]. ${ }^{46}$

Considero que el hallazgo de esta noticia resulta de gran trascendencia, pues viene no sólo a precisar el año en que nació (1638) - dato que, como veremos más adelante, resulta también de gran importancia- ,47 sino, mejor aún, porque viene a echar por tierra la acariciada sospecha, manejada por prácticamente todos los autores, de que este destacado pintor hubiese nacido en España.

Y no obstante que, como hemos visto, el doctor C astro ya aventuraba prudentemente la posibilidad de que hubiese nacido en $M$ éxico, y que con ello parecía desprenderse de la creencia de que fuese originario de España, idea que hasta entonces prevalecía, $4^{8}$ es curioso que, al final, no concediera mayor importancia al punto relativo al lugar de su nacimiento. Ahora podemos afirmar abiertamente que no es un artista español, que nació en M éxico, en i638, y que, por ende, fue contemporáneo de Baltasar de Echave Rioja, ese otro connotado pintor novohispano, con quien se le suele citar, nacido sólo seis años atrás, en I632.

Tal y como hemos visto, fue el tercero de los ocho hijos del matrimonio formado por el ensamblador y escultor Pedro Ramírez, el viejo, y doña I sabel de Contreras. 49

D esconocemos cómo y dónde transcurrió su infancia y adolescencia. Y aunque sabemos que nuestro pintor contrajo matrimonio con Josefa Gómez de Prado o de Rivera, falta precisar en qué fecha y lugar, pues al menos en el archivo de la parroquia de la Catedral de M éxico no hay ninguna informa-

46. ASM, Libro I3 de bautismos de españoles, I634-I639, f. 345V. Como se podrá apreciar, fungieron como padrinos su abuelo paterno y su abuela materna.

47. Sobre este último punto también Efraín C astro sólo se aventuró a proponer que habría nacido "en la tercera década del siglo XvII". Ahora podemos constatar que sus cálculos eran correctos.

48. El único en afirmar que "fue mexicano" - pero sin indicar en qué fundamentaba su aseveración- fue Ernesto Sodi Pallares, Pinacoteca virreinal de San Diego, M éxico, Populibros La Prensa, 1969, p. 61.

49. Y, como también ya sabemos, fueron sus hermanos ) uan Ramírez de Contreras (clérigo presbítero), Josefa, Laureano Ramírez de Contreras, el conocido ensamblador, Agustina, Agustín Ramírez de Contreras (clérigo presbítero), M atías y José Ramírez (acuñador de la Real Casa de M oneda). 
DOI: http://dx.doi.org/10.22201/iie.18703062e.2000.77.1948

78

ROGELIO RUIZ GOMAR

ción sobre el particular; 50 por lo mismo, quisiera adelantar que muy posiblemente dicho enlace se efectuó en la ciudad de Puebla, puesto que como veremos más adelante, sus primeros hijos nacieron en esa ciudad. Q uisiera señalar, asimismo, que el que no se haya podido localizar aún la partida de amonestación correspondiente nos impide saber también quiénes eran los padres de la esposa. Sin embargo, en virtud de la repetición de los apellidos, bien pudiera ésta resultar hija o hermana del Agustín Gómez de Prado - casado con Teresa de Contreras- , cuyo hijo Diego, tal y como ya señalamos, fue llevado a bautizar por Pedro Ramírez padre, el 23 de octubre de $1646 .^{\mathrm{SI}}$ Sea como fuere, nuestro pintor procreó con ella por lo menos ocho hijos: Isabel, M icaela, M iguel, Pedro, Gertrudis (I666), Joseph (I668), N icolasa (I670) y Antonio (I672).52

I gnoramos las fechas de nacimiento de los cuatro primeros, pues nacieron en la ciudad de Puebla, pero sí conocemos las de los otros cuatro, ya que fueron bautizados en la parroquia de la Catedral M etropolitana. En I666 nació Gertrudis, de quien fue padrino un bachiller llamado Juan M éndez de Alegría. ${ }^{33} \mathrm{D}$ os años después, en diciembre de i668, nacería Joseph, cuya ceremonia de bautizo fue presidida por el doctor $M$ anuel de Escalante y $M$ endoza, importante personaje del cabildo de la $C$ atedral de $M$ éxico de ese entonces. ${ }^{54}$

50. Según apunta Efraín Castro, su mujer llevó de dote sólo cien pesos. Q uizá a causa de ello, o por haber colaborado en el taller paterno, su padre le obsequió en su boda 996 pesos y 6 tomines, "así para su sustento, como [para] pagar la casa en que ha vivido"; op. cit., p. 22.

5I. Vid. supra nota i8. O tra hija del dicho Agustín Gómez de Prado, doña Gertrudis de Contreras, se casaría en la ciudad de M éxico en mayo de ı680 con M artín D elgado V illalpando - viudo de M agdalena de los Reyes y quien también por su apellido acaso resulte emparentado con el afamado pintor Cristóbal de Villalpando. Empero, lo que ahora me interesa destacar es que en la partida de amonestación correspondiente se asevera que la contrayente era natural de Puebla, y que era vecina de la ciudad de M éxico hacía quince años. Y no está de sobra el retener el dato de que hacia i685 se encontraría activo en la ciudad de Puebla un escribano de nombre Pedro G ómez de Prado.

52. Efraín Castro extrae del testamento del pintor los nombres de sólo seis hijos, que seguramente para los últimos días del artista aún vivían: I sabel, M iguel, Pedro, Gertrudis, José y N icolasa Ramírez; pero habrá que agregar los de al menos otros dos - M icaela y Antonio- , de cuya existencia dan fe, como veremos, otros documentos.

53. ASM , Libro $2 I$ de bautismos de españoles, f. 235 .

54. Fue su padrino el capitán don Fernando de Ibarra (Ybarra). ASM, Libro 22 de bautismos de españoles, $I 667-1669$, f. I35V. Escalante y M endoza fue originario de Lima, Perú, pero su formación y su carrera las llevó a cabo en la N ueva España, a la que llegó cuando su padre fue nombrado fiscal de la Audiencia de M éxico. H izo sus estudios en la U niversidad de M éxico, 
A finales de septiembre de i67o fue bautizada $\mathrm{N}$ icolasa, de quien fue padrino su tío el bachiller Agustín Ramírez.55 Por último, en agosto de 1672 fue bautizado Antonio, de quien acaso fue padrino el otro tío José Ramírez, quien para ese año de 1672 sumaba 22 de edad y no era aún ensayador en la Casa de M oneda, 0 al menos no se especifica nada de ell $0 .{ }^{56}$ Sea como fuere, este niño murió a escasos dos años de edad, el 30 de agosto de i674. D e la partida de defunción extraemos la noticia del domicilio de nuestro pintor, pues se dice que el niño "vivía junto a la Pila Seca de Santo Domingo"; fue enterrado en el cementerio de la catedral. ${ }^{57}$

$D$ ato hasta ahora ignorado y que conviene subrayar es el de que el pintor y su esposa residieron por un tiempo en la ciudad de Puebla. Sobre este punto, ya señalé cuán significativo resulta que no se encuentren en la parroquia del Sagrario de la Catedral de M éxico ni el registro de las amonestaciones que se debieron pregonar para la verificación de su matrimonio ni la partida del matrimonio en sí, pero más aún que tampoco se localicen las partidas de bautizo de sus primeros cuatro hijos: Isabel, M icaela, M iguel y Pedro, que, insisto, habrá que buscar en los archivos parroquiales de Puebla, ciudad en la que, como veremos a continuación, nacieron. En efecto, llegado el momento, y ya avecindados aquéllos en M éxico, se habría de asentar tanto en las respectivas partidas de amonestación de Isabel, $\mathrm{M}$ icaela y $\mathrm{M}$ iguel, como en el testamento de Pedro - quien se hizo sacerdote- , que eran originarios de la dicha ciudad de Puebla, si bien vecinos de esta de M éxico desde pequeños. I sabel, que parece haber sido la hija mayor, se casó en noviembre de i676 con

en la que se doctoró en i668, y fue maestro y rector. Fue abad de la congregación de San Pedro, ubicada en la iglesia de la Santísima, de la que, como hemos visto, fue miembro el bachiller Agustín Ramírez de Contreras. Asimismo, fue tesorero y chantre de la Catedral de $M$ éxico hasta finales de i7oo, en que fue designado obispo de $D$ urango, y posteriormente de M ichoacán, tocándole en suerte la consagración de su catedral. Existe un retrato suyo, así como otro de su hermano J uan, realizados por el afamado Juan Rodríguez J uárez; el del primero forma parte del patrimonio artístico de la U niversidad N acional Autónoma de M éxico, y el del segundo se custodia en el $\mathrm{M}$ useo $\mathrm{N}$ acional del Virreinato.

55. Vid. supra notas 36 y 39, e infra nota 70. (ASM, Libro 23 de bautismos de españoles, 1670 I672, f. 7IV).

56. Vid. supra nota 43. (ASM, Libro 24 de bautismos de españoles, I672-I676, f. 4).

57. ASM, Libro $I$ de defunciones de españoles, I67I-I680, f. 96. Para lo referente a la mencionada calle, vid. infra nota 78 . 
DOI: http://dx.doi.org/10.22201/iie.18703062e.2000.77.1948

80

ROGELIO RUIZ GOMAR

Agustín N avarro ${ }^{8}$ y murió el i7 de diciembre de i690.59 Por su parte M icaela Ramírez - cuyo programado matrimonio con Juan Becerra, en julio de I679, no se verificó, debido quizá al muy cercano y triste deceso de los dos Pedros Ramírez- , terminó casándose en noviembre de ese mismo año con M iguel Ramírez de Espinosa. ${ }^{60}$ Y por lo que toca a M iguel Ramírez de C ontreras sabemos que se casó el 9 de junio de $\mathbf{1} 68$ o con N icolasa de San Pedro 0 de Q uiñones, y que fue testigo del enlace su tío, el bachiller Juan Ramírez. ${ }^{61}$ Pese a que hasta donde sabemos fue el primero de los varones, este hijo no parece haber continuado el oficio del padre.

Por último, hijo también nacido en la ciudad de Puebla, pues aś lo declaró en su testamento, fue Pedro, el tercero con este nombre en la familia. Éste, al igual que dos de sus tíos, siguió la carrera eclesiástica, por lo que en las pocas e incidentales noticias que de él recogí en el archivo del Sagrario, aparece como el "bachiller Pedro Ramírez de Contreras" (acorde con las normas actuales debería ser, en todo caso, Gómez). El 4 de noviembre de 1674 figura como testigo en la boda de Blas de Vega con Inés de Abarca, ${ }^{62}$ y en noviembre de i683, en compañía de José Ramírez - seguramente su tío, pues su hermano del mismo nombre apenas tenía once años- , como testigo del ma-

58. Era hijo de Juan N avarro y M aría H idalgo; ASM , Libro II de amonestaciones de españoles, I670-I680, f. I49. Según Efraín Castro, el dicho Agustín N avarro era maestro tirador de oro, op. cit., p. 24. De la confianza que le profesara su suegro queda el dato de que Pedro Ramírez le designara como al bacea en su testamento; vid. infra nota 78 .

59. ASM, Libro 3 de defunciones de españoles, I687-I692, f. I94. Inmediatamente después de enviudar el dicho Agustín $\mathrm{N}$ avarro inició los trámites eclesiásticos para casarse con $\mathrm{M}$ aría de las $\mathrm{N}$ ieves - viuda, a su vez, de Francisco de Alcalá- , en diciembre de I690: ASM, Libro I3 de amonestaciones de españoles, I688-I694, f. $72 \mathrm{~V}$.

6o. Curiosamente, en la primera partida de amonestación se asevera que ella había nacido en Puebla, pero en la segunda que era "natural y vecina" de la ciudad de M éxico. Como no cabe pensar que se trata de dos personas diferentes, hay que considerar que en la segunda hubo un error. El hombre con el que terminó casándose era hijo de D omingo Ramírez de Espinosa y M aría de Cabañas). ASM, Libro $I I$ de amonestaciones de españoles, $1670-I 680$, fs. $202 \mathrm{~V}$ y 2 IO.

6I. Vid. infra nota 31. Ella era hija de Tomás de San Pedro y de Isabel de Q uiñones (ASM, Libro $I I$ de amonestaciones, I670-I680, f. 22IV, y Libro $I I$ de matrimonios de españoles, I680-I688, f. 8), y no habría de morir hasta mayo de I734. En la partida de defunción se asentó que vivía detrás de Santa Teresa la Antigua y que fue enterrada en la I glesia de la Santísima Trinidad. ASM , Libro $I I$ de defunciones de españoles, $I 734-I 737$, f. 2 IV.

62. ASM, Libro Io de matrimonios de españoles, I672-I674, f. 84V. 
trimonio de M aría Teresa, la hija de Laureano, con José de O Imedo. ${ }^{63}$ En junio de ${ }_{1702}$ oficia en el bautismo de $\mathrm{M}$ anuela Teresa, hija de su hermana $\mathrm{N} \mathrm{i-}$ colasa, y en febrero y julio de I703, en el bautizo de dos niños de nombre Pedro, el segundo de los cuales fue "expuesto en casa de doña I sabel de Contreras, en la calle de Balbanera". ${ }^{64} \mathrm{En}$ los años subsecuentes lo volvemos a encontrar bautizando a otros tres niños: a Francisco, en octubre de I704; a Francisco Xavier, en noviembre de I7Io, y a M aría Xaviera, en junio de I7II; y, finalmente, en mayo de i7II, fungiendo como padrino de bautizo de otro niño, Francisco Xavier Pedro. ${ }^{65}$ Se ignora la fecha de su muerte, pero hizo testamento el 2 de abril de ${ }_{1725}$, ante el notario Felipe M uñoz de Castro. ${ }^{66} \mathrm{El}$ que se hiciera clérigo explica, en buena medida, que tampoco este hijo siguiera los pasos del padre y que, por consecuencia, nuestro pintor se quedara sin sucesor artístico directo.

Regresemos con las noticias reunidas en torno a los hijos nacidos en la ciudad de M éxico. Gertrudis Ramírez de Contreras se casó en abril de i684 con Bentura de M urillo y Peralta, ${ }^{67}$ y tuvo tres hijos: Francisco Javier (1690), Juan D omingo (1692) y M aría M agdalena (1694). ${ }^{68}$ Es probable que alguna complicación derivada del último parto (en el mes de septiembre) provocara su muerte, que ocurrió el is de octubre de ese año de i694; por la partida de defunción sabemos que vivía frente a la casa Profesa. ${ }^{69}$

Nicolasa contrajo matrimonio en mayo de i687 con Simón Fernández de Isla - "natural de la ciudad de Cholula" y vecino de la de M éxico desde ha-

63. Vid. supra nota 44 e infra nota 85.

64. ASM , Libro 33 de bautismos de españoles, I70I-I705, fs. I22 (vid. infra nota 70), I88 y $232 \mathrm{~V}$. D el segundo fueron padrinos N icolás Gómez y doña Ana Romo.

65. ASM, Libro 33 de bautismos de españoles, I70I-I705, f. 356V, y Libro 35 de bautismos, I709I7I2, fS. 210,276 y $284 \mathrm{~V}$.

66. Archivo G eneral de N otarías, notario 39I, libro 2580, fS. I2I-I22; citado por M ina Ramírez M ontes, en Catálogos de D ocumentos de Arte, I5. Archivo General de N otarías, M éxico. Ramo: Protocolos, M éxico, U niversidad N acional Autónoma de M éxico, Instituto de Investigaciones Estéticas, 1990, ficha I28, p. 20.

67. ASM , Libro I2 de amonestaciones, f. 92.

68. Las correspondientes partidas de bautismo están en ASM, Libro 29 de bautismos de españoles, f. I99, y Libro 30 de bautismos de españoles, fS. 5 I y 236. N o deja de ser extraño el hecho de que en esta última se registre a la madre como "doña Gertrudis de Arellano".

69. ASM , Libro 4 de defunciones, $1693-1698$, f. $94 \mathrm{~V}$. 
DOI: http://dx.doi.org/10.22201/iie.18703062e.2000.77.1948

82

ROGELIO RUIZ GOMAR

cía i2 años-, boda en la que ofició su tío el bachiller Agustín Ramírez de Contreras, el mismo que la había apadrinado en su bautizo. ${ }^{70}$

D e sus otros dos hijos, José (J oseph) y Antonio, casi nada puedo agregar a las fechas ya consignadas de sus bautizos en i668 y i672, respectivamente. Respecto del primero, sabemos que aún vivía para cuando el padre hizo testamento - tendría escasos cinco años- , pero difícilmente podríamos aceptar que se trata del José Ramírez que el 6 de noviembre de 1683 funge como testigo en el matrimonio de José de O Imedo y M aría Teresa, la hija de Laureano, pues sólo tenía once años de edad. Por lo que toca al segundo, murió cuando tenía sólo dos años de edad. ${ }^{71}$

Regresando con el pintor Pedro Ramírez de Contreras, el mozo, un punto importante que falta precisar es el relativo al número de años que vivió en Puebla, y entre qué fechas hay que situar su permanencia en dicha ciudad. Futuras investigaciones vendrán a aclarar esos puntos. Por ahora nos conformamos con proponer que su regreso definitivo a la ciudad de M éxico debió de ocurrir hacia los últimos años de la década de los cincuenta, puesto que, como ya vimos, al tiempo de casarse sus hijos declararían que eran naturales de Puebla, pero vecinos de la ciudad de M éxico desde pequeños. N ecesariamente su regreso se verificó antes del mes de marzo de i666, en que, tal y como se ha dicho, lo encontramos acudiendo a la parroquia de la $C$ atedral M etropolitana para bautizar a su hija G ertrudis. A partir de entonces su presencia en la ciudad capital está documentada por los subsecuentes hijos que llevó a bautizar y por otras noticias extraídas de los registros de la parroquia catedralicia. Así, por ejemplo, sabemos que fue padrino de bautismo de varios niños: en enero y octubre de 1672 de Diego y Francisco (hijos, el primero, de Diego Caro del Castillo y N icolasa de Contreras, ${ }^{72}$ y de Jacinto de $M$ ontes de 0 ca y $M$ anuela González, el segundo). ${ }^{73}$

70. Vid. supra notas 36, 39 y 55. ASM, Libro 12 de amonestaciones de españoles, I680-I687, f. I6o, y Libro $I I$ de matrimonios de españoles, I680-I688, f. 327V. De este matrimonio nació Teresa $M$ anuela (bautizada el 23 de diciembre de 1698 , y de quien fue madrina su bisabuela doña I sabel de Contreras, vid. ASM, Libro 22 de bautismos de españoles, I698-I70I, f. I2V.), M anuela T eresa (llevada a bautizar en junio de I702, en ceremonia oficiada por su tío el Br. Pedro Ramírez de Contreras y donde fue padrino Antonio Caro del Castillo) y M iguel (llevado a bautizar en octubre de 1703 también por su bisabuela I sabel de Contreras). ASM , Libro 33 de bautismos de españoles, I70I-I705, fs. I22 y 256, respectivamente.

7I. Vid. infra nota 57.

72. ASM, Libro 23 de bautismos de españoles, $1670-1672$, f. 208.

73. ASM , Libro 24 de bautismos de españoles, $1672-1674$, f. I9. 
Y aunque era algo que cabía esperar, quisiera destacar que entre los niños que llevó a la pila bautismal también se encuentran hijos de connotados pintores. Es el caso de M aría, hija de Baltasar de Echave Rioja y Ana del CastiIlo, a la que apadrinó el i2 de febrero de i662,74 y de Félix, hijo de Cristóbal de Villalpando y $M$ aría de $M$ endoza, en junio de $1672 .{ }^{75}$ D e esta manera, podemos constatar que, más allá de la relación que nacía de compartir un mismo oficio, Pedro Ramírez estrechó su relación con dos de los más importantes pintores de su tiempo, merced a ese vínculo de esencia espiritual, pero tan importante para aquella época, que es el compadrazgo. Empero, no se puede descartar que el padrino en el primero de los casos fuera Pedro Ramírez, el viejo, puesto que para febrero de i662 nuestro pintor aún no cumplía los 22 años. Pero si, como creo, se trata de nuestro pintor y no del padre o de un homónimo, entonces resultaría que Pedro Ramírez, el joven, ya estaba de regreso en M éxico desde ese año de i662. En el segundo caso, no cabe la menor duda de que sí se trata del pintor, pues figura en compañía de su esposa Josefa Gómez.

En otro orden de ideas, consignemos el dato de que en mayo de i672 le vendía una esclava a Andrea de $M$ endoza. ${ }^{7}$

Mucha razón tuvo Efraín Castro cuando escribió que Pedro Ramírez el mozo sobrevivió poco a la muerte de su padre. Para afirmar lo anterior se basó en el hecho de que el 9 de abril de i679, encontrándose enfermo y no pudiendo asistir a los inventarios y avalúo de los bienes dejados por aquél, otorgó poder al alférez Jerónimo de Savallos para que acudiese en su nombre; así como en el dato de que para el 28 de abril de ese mismo año otorgaba testamento ante el escribano Francisco de Prado. ${ }^{77}$ Ahora puedo precisar que murió el 2 de junio de ese mismo año. Importa transcribir, pues, la partida de su defunción que obra en el archivo del Sagrario, habida cuenta de que corrobora algunas de esas noticias y nos proporciona la fecha precisa de su muerte:

En 2 de junio de 1679 murió Pedro Ramírez de Contreras, casado con doña J osefa de Ribera; testó ante Francisco de Prado, escribano real, a 28 de abril de este

74. ASM, Libro 20 de bautismos de españoles, $1660-1663$, f. I32V.

75. ASM, Libro 23 de bautismos de españoles, I670-1672, f. 268.

76. Vid. M ina Ramírez M ontes y G uillermo Luckie, Catálogos de D ocumentos de Arte, I6. Archivo G eneral de N otarías de la Ciudad de M éxico. Ramo: Protocolos I, M éxico, U niversidad $\mathrm{N}$ acional Autónoma de M éxico, Instituto de Investigaciones Estéticas, I993; ficha I03, p. 32.

77. 0 p. cit., p. 24 . 
DOI: http://dx.doi.org/10.22201/iie.18703062e.2000.77.1948

84

ROGELIO RUIZ GOMAR

presente año. D ejó por sus al baceas a doña Josefa de Ribera, su esposa, y a Agustín $\mathrm{N}$ avarro, su hijo [yerno], y por sus herederos a sus hijos. M andó decir ıoo misas rezadas. Vivía en la Pila Seca de Santo D omingo. Enterróse en el Carmen. Caven de la cuarta de las misas -25 misas. ${ }^{78}$

En lo que toca a los bienes que heredó de su padre, gracias a Efraín C astro sabemos que pasaron a sus hijos de acuerdo con la transacción y concierto que siete años después habrían de efectuar sus al baceas ( 23 de diciembre de I686). 79

Su esposa le sobrevivió varios años, pues no murió hasta el 29 de abril de I703. En la partida de defunción se asentó que "vivía en el callejón de las Cruces", y que murió sin hacer testamento. ${ }^{80}$

\section{Laureano Ramírez de Contreras}

Por lo que toca a Laureano Ramírez de Contreras, reuní también varias noticias. Respecto de su nacimiento, Efraín C astro sólo pudo apuntar que "nació en la ciudad de M éxico, quizá en la cuarta o quinta década del siglo XVII". Pues bien, el futuro ensamblador nació en dicha ciudad de M éxico a principios del mes de julio de I640, ya que fue bautizado el día ı2 de ese mes y año en la parroquia catedralicia. Fueron sus padrinos Tomás de Palencia y M aría de Contreras, acaso tíos suyos, hermanos de su madre. ${ }^{8 \mathrm{I}} \mathrm{El} \mathrm{I}^{\mathrm{0}}$ de marzo de I665, poco antes de cumplir los 25 años, se casó con doña M aría de la M uela y Castro, "natural de esta ciudad, hija de Juan Rodríguez de la Muela y de doña Ysabel de C astro". ${ }^{82}$ D e este enlace nacieron sólo dos hijas: M aría Tere-

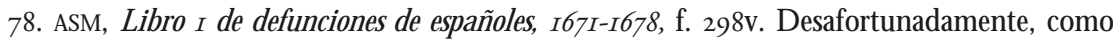
señala Efraín Castro, no contamos con dicho testamento, pues no se conservan los papeles del notario en cuestión. La calle de la Pila Seca corría de oriente a poniente (actual $3 a$. de Belisario D omínguez), y ocasionalmente también se le llamó calle de la cerca de Santo D omingo. Vid. E duardo Báez M acías, "Planos y censos de la ciudad de M éxico. I793", en Boletín del Archivo General de la Nación, 2a. serie, t. vII, núms. I-2, M éxico, Secretaría de Gobernación, I966, p. 437.

79. Op. cit., p. 36.

80. ASM, Libro 5 de defunciones, I698-I707, f. 20IV.

8I. ASM , Libro I4 de bautismos de españoles, I640-I643, f. 40.

82. ASM, Libro 9 de amonestaciones de españoles, I662-I666, f. 53. Los casó el doctor don N icolás del Puerto, canónigo de la catedral y provisor y vicario general del arzobispado de M éxico, 
sa, que fue llevada a la pila bautismal el 30 de septiembre de i668 por su abuelo Pedro Ramírez, ${ }^{83}$ y M aría, que fue apadrinada por el dicho Juan Rodríguez de la Muela, su abuelo materno, y bautizada por el bachiller Juan Rodríguez (¿de la M uela?, en ese caso posiblemente hijo del anterior) en diciembre de $1670{ }^{84}$ Esta última murió a temprana edad, pues, como veremos a continuación, para ı689, en que hizo testamento el dicho abuelo materno, no figura entre sus herederos. Por su parte, M aría Teresa, la primera hija, habría de casarse el 2I de noviembre de ${ }_{1} 683$ con José de 0 Imedo y Luján, siendo testigos Luis Rodríguez Palacio, su tío abuelo José Ramírez y su primo el bachiller Pedro Ramírez. ${ }^{85}$

No deja de ser curioso el que encontremos a Laureano emparentándose no con artesanos cercanos a su propio oficio, sino con comerciantes. En efecto, tanto su suegro, Juan Rodríguez de la Muela, como su yerno, O Imedo y Luján, eran mercaderes.

El primero, según declaró en el padrón que en i689 se levantó de los peninsulares que vivían en la ciudad de M éxico, era natural de M ilmarcos, en Castilla, y mercader con almacén. M urió el in de febrero de i69o. En su testamento (ante Baltasar M orante, 6 de julio de i689) designó como albaceas a José Rodríguez - acaso su hermano- y a José de O Imedo y Luján, casado con su nieta, y como herederos al mismo José Rodríguez y a sus nietos, doña M aría Teresa Ramírez - casada ya con el dicho O Imedo y Luján- , sor M aría de San Juan - religiosa en el convento de Santa Catalina de Siena- y a José Díaz Cuéllar. D on Juan Rodríguez de la M uela vivía en la calle de Balvanera y se le enterró en la M erced. Por su parte, José de O Imedo y Luján declaró ser, igualmente, mercader y natural de Sevilla, con ıo años de vivir

siendo testigos "Ios reverendos padres maestro fray Juan de Andrada y fray Juan de Pareja": ASM , Libro 8 de matrimonios de españoles, I657-I667, f. 23IV.

83. ASM, Libro 22 de bautismos de españoles, I667-I669, f. II9; vid. supra nota 2 I.

84. ASM, Libro 23 de bautismos de españoles, $1670-1672$, f. 89v. Acaso se trata de su tío, el bachiller J uan Ramírez (vid. supra nota 3I); empero, no se puede descartar que se trate del bachiIler Juan Rodríguez de la M uela, también pariente, pero por la vía materna.

85. Vid. supra notas 44 y 63. Los casó fray Francisco Jiménez, dominico, y se velaron en Coyoacán, el 25 de ese mismo mes y año. Él era viudo de M aría Teresa Coto: ASM, Libro I2 de amonestaciones de españoles, I680-I687, f. 76. D e este matrimonio sólo recogí la noticia de un hijo, Pedro I gnacio, que fue llevado a bautizar el 3i de enero de i690; fue su padrino J uan Rodríguez de la M uela. ASM, Libro 29 de bautismos de españoles, I688-I69I, f. 172. 
DOI: http://dx.doi.org/10.22201/iie.18703062e.2000.77.1948

86

ROGELIO RUIZ GOMAR

en M éxico. Tras enviudar, pasó a terceras nupcias con Antonia de Esquivel y Contreras, natural de Salvatierra. M urió el 8 de julio de ${ }_{1708}{ }^{86}$

$M$ as volviendo a Laureano Ramírez de Contreras, ya Efraín C astro apuntó que, tras enviudar de M aría de la M uela, había contraído segundas nupcias con Josefa M árquez de Arce. En efecto, en enero de 1677 se casó con doña Josefa de Arce (Arze) y M oxica, o M árquez, "natural y vecina de la villa de Cuioacán, hija legítima de Antonio Márquez y de doña Josepha de Arce y M oxica" ${ }^{87}$ De este segundo matrimonio habrían de nacer cinco hijos más: M atiana Josefa (I679), José M anuel (I68I), Inés (I683), Antonia Clara (I685) y Juana Laureana (I686). ${ }^{88}$ Val ga anotar que la primera hija, M atiana Josefa, murió el 22 de mayo de i68I, a escasos dos años y dos meses de edad, no "de 304 años", como se asentó en la partida correspondiente. ${ }^{89}$ Por ella sabemos que Laureano vivía "en la calle del Relox, enfrente del campanario de Santa Catalina de Sena".

De la tercera hija, Inés Ramírez M árquez de Arce, las pesquisas en el archivo del Sagrario arrojaron la noticia de que contrajo matrimonio a finales de i7or con el "oficial y tesorero de la Real Caja" Lorenzo Pérez Caro, de quien se asienta que era "natural del Real y minas de San José del Parral", pero que residía en la ciudad de M éxico desde hacía 6 años. En la ceremonia ofició un personaje que estará presente en otros eventos importantes de la familia: don Domingo Antonio Bayón Bandujo, capellán de honor de Su M a-

86. Vid. José Ignacio Rubio M añé, "Gente de España en la ciudad de M éxico. Año de I689", en Boletín del Archivo General dela N ación, za. serie, vol. vII, núms. I-2, M éxico, Secretaría de Gobernación, 1966, pp. I03-104.

87. ASM, Libro II de amonestaciones, I670-I680, f. I54.

88. Las partidas de bautismo de los dos primeros están en ASM, Libro 26 de bautismos de es pañoles, I679-I682, fS. 2 y I77V. En el bautizo de la primera (5 de marzo de i679) ofició su tío, el Br. Agustín Ramírez (vid. supra nota 37). En el de José M anuel (I3 de abril de I68I) fue padrino el capitán Juan Rodríguez de la M uela, pariente de la primera esposa de Laureano, Io que permite observar que mantenía buenas relaciones con ellos. Las partidas de Inés ( 23 de abril de 1683 ) y de Antonia Clara (7 de enero de I685) están en ASM, Libro 27 de bautismos de españoles, I682-I685, fs. 76V y 228. D e Inés fue padrino el licenciado don Bartolomé de Yzasi y Pardo, "cura beneficiado del pueblo de Teoloyucan", y de Antonia Clara el capitán Diego de Frías. Por último, la partida de Juana Laureana (i4 de julio de I686) - por la que sabemos que fue padrino el P. M aestro, fray N icolás de Vargas, dominico, y que ofició fray Lorenzo Rodríguez de la M uela- , está en ASM, Libro 28 de bautismos de españoles, 1685 - I688, f. $75 \mathrm{~V}$.

89. Fue enterrada en la iglesia de Santa C atalina de Sena. ASM, Libro 2 de defunciones de es pañoles, I68I-I686, f. 20. 
DOI: http://dx.doi.org/10.22201/iie.18703062e.2000.77.1948

NUEVAS NOTICIAS SOBRE LOS RAMÍREZ

jestad, consultor del Santo O ficio de la Inquisición, y canónigo de la Catedral de M éxico. Asimismo, uno de los testigos fue José de la Serna, oficial de la contaduría de tributos. 90

Pero es de la cuarta hija, Antonia C lara Ramírez M árquez, de quien el archivo arrojó las más inesperadas noticias. D estaca la de que el 2 de agosto de 1703, dispensadas "las tres amonestaciones que manda el santo Concilio... por justos motivos", la susodicha se casó con don Juan Pérez Cancio de la Vega, natural del "Lagar de Val de Do [sic] en el Consejo de Castro Pol [sic] en el principado de Asturias", y residente en M éxico desde hacía nueve años. ${ }^{91} \mathrm{D}$ e este matrimonio nacieron cinco hijos, si bien el primero de ellos vino al mundo cuando aún los progenitores no estaban casados. En efecto, en la partida de bautizo de Gregorio José Bernardo ( 28 de septiembre de I70I) se señala que fue expuesto en la casa del citado don D omingo Antonio Bayón y Bandujo, quien fue también su padrino: el niño, según una nota puesta al margen, fue reconocido como hijo legítimo por auto proveído el 3 de enero de 1705 , hasta después de que aquéllos contrajeron matrimonio.92 Los cuatro hijos restantes fueron Domingo José Antonio Bernardo (I706),93

90. El dicho Lorenzo Pérez Caro era hijo de Francisco Pérez Caro y doña I sabel García Penalo: ASM, Libro Is de amonestaciones de españoles, I70I-I706, f. I8V, y Libro $I_{3}$ de matrimonios de españoles, I694-I70I, fs. 290-290V. D e este enlace sólo recogí la noticia de una hija, Josefa I sabel, que fue llevada a bautizar el I3 de julio de I7II: ASM, Libro 35 de bautismos, f. $289 \mathrm{~V}$. Pe ro también fueron padres del bachiller Jerónimo Antonio Pérez Caro, quien disfrutaría de la capellanía fundada por Pedro Ramírez, el viejo, entre 1733 y 1759.

9I. Él era hijo de Antonio Pérez Cancio y doña M aría Álvarez de Villa Abril: ASM, Libro Is de amonestaciones de españoles, $170 I-I 706$, f. $53 \mathrm{~V}$. Fueron testigos del enlace J osé D iez O rtuño, escribano de provincia y, al igual que en la boda de la hermana, de nueva cuenta José de la Serna, oficial de la Contaduría de Tributos. La ceremonia fue presidida por el mismo don D omingo Antonio Bayón Bandujo, y la velación se verificó en la iglesia de Los Remedios, el 7 de enero de 1705 , tal y como se asentó en nota marginal a la partida de matrimonio: ASM, Libro ${ }_{4}$ de matrimonios de españoles, I702-I7I3, fS. 5O-5IV.

92. ASM, Libro 33 de bautismos de españoles, I70I-I705, f. 4IV. A su tiempo, este niño habría de casarse, en junio de I7I9, con doña M aría de los D olores Fernández de Villaseñor y Salgado - hija de M artín Fernández Salgado y doña M aría de Contreras y Villaseñor Rangel- , natural y vecina del pueblo de San Juan del Río, en el actual estado de Q uerétaro, ASM , Libro I7 de amonestaciones de españoles, I7I4-I7I9, f. I35.

93. N ació el 16 de febrero de 1706 y fue bautizado el 22 de ese mes y año. Fue su padrino el licenciado don J osé Y báñez de la M adrid y Bustamante, tesorero de la catedral: ASM, Libro 34 de bautismos de españoles, $1705-1708$, fs. $40 \mathrm{~V}-4 \mathrm{I}$. 
DOI: http://dx.doi.org/10.22201/iie.18703062e.2000.77.1948

88

ROGELIO RUIZ GOMAR

Francisco José Bernardo Antonio (I709), ${ }^{94}$ M aría Josefa Bernarda (I7iI) y Juan Felipe (1713). 95

Estas noticias vienen a subsanar la falta de información observada por Efraín C astro cuando aseveró que Laureano "tuvo al gunos hijos, cuyos nombres desconocemos"; pero no faltó a la verdad cuando agregó que lo que sí podía asegurarse era "que no tuvieron ninguna actividad vinculada con el arte". ${ }^{96}$

Sin embargo, merece destacarse la noticia de que un hijo de aquel que fue legitimado, y por ende un bisnieto de Laureano, sería el célebre doctor Gregorio Antonio Pérez Cancio y Vega, cura y constructor de la iglesia parroquial de la Santa Cruz y Soledad, y autor de la memoria de fábrica de dicho templ0.97

Terminemos de redondear ahora con los datos extraídos del archivo del Sagrario M etropolitano la construcción de la biografía de Laureano Ramírez de Contreras. Páginas atrás lo encontrábamos junto con su padre o hermano, fungiendo como testigo en dos bodas: en la de su tía Francisca - sólo cuatro años mayor que él- con José de Castro (en agosto de i663), y en la de M atías de U ribe con doña Luisa de Vargas ( ( ${ }^{\circ}$ de marzo de I669)..${ }^{98} \mathrm{~A}$ estos datos, añadamos que lo hallamos igualmente como testigo, ahora junto con su suegro Juan Rodríguez de la M uela, en la boda de Francisco Pimentel y doña

94. Fueron sus padrinos el capitán don Agustín Ignacio de Vidarte y doña Feliciana de la Cueva y Soto: ASM, Libro 35 de bautismos de españoles, I709-I7I2, fS. $73 \mathrm{~V}-74$.

95. Las partidas de bautismo de los dos últimos están en ASM, Libro 35 de bautismos, f. $307 \mathrm{~V}$, y Libro 36 de bautismos, f. I69, respectivamente.

96. 0 p. cit., p. 34.

97. Vid. Gregorio Pérez Cancio, La Santa Cruz y Soledad de N uestra Señora. Libro de fábrica del templo parroquial, edición e introducción de Gonzalo O bregón, M éxico, Instituto N acional de Antropología e H istoria, 1970. Respecto de este doctor Gregorio Pérez Cancio, Gonzalo 0 bregón asentó que era hijo de Bernardo José Gregorio Pérez Cancio y de doña M aría D olores Fernández Contreras Villaseñor y M onroy, ambos "gentes de dinero y con buena posición social". I gnoro de dónde obtuvo tal noticia, pero aún agregó que el padre era "originario y vecino de San Juan del Río" y que ella lo era posiblemente de la zona de M ichoacán, y descendiente de un famoso encomendero del siglo XVI (“Introducción”, p. 9). Contrástese esta información con la que hemos recogido atrás, en las notas 9 I y 92.

98. ASM, Libro 8 de matrimonios de españoles, I667-I672, f. I80, y Libro o de matrimonios I667-I672, f. 36V. En ambos, como vimos, ofició el bachiller Juan Ramírez. Vid. supra notas 6,29 y 35 . 
Juana M anuela de León (2I de enero de I669),99 y a él solo como testigo en la boda de don Francisco de Vargas y doña I sabel de la Cueva ( 5 de febrero de I673). ${ }^{\text {.00 }}$

El 23 de junio de 1664 fue padrino de la niña Francisca Xaviera, hija de Juan Pérez Calderón e Isabel de Cárdenas Benavides. ${ }^{\text {Io }}$ Como dato curioso habría que recoger la noticia de que a mediados de i68o dejaron expuesto en la casa de Laureano a un niño al que pusieron por nombre Joseph, del que fue madrina doña M agdalena de Bustos. ${ }^{102}$

Asimismo, encontramos a Laureano y a su segunda esposa como padrinos de bautismo de dos niños: de José Raimundo (io de septiembre de i682), hijo del bachiller Juan de Avilés Ramírez, médico, y de doña Antonia Sofía, ceremonia en la que, como vimos, ofició el bachiller Agustín Ramírez y Contreras, y de José Jorge (i6 de mayo de i683), hijo de Juan G erónimo Solano de $\mathrm{M}$ endoza y de Antonia Rodríguez de C astro; ${ }^{103}$ y él solo también se encuentra como padrino del niño Joaquín José ( 2 de abril de i686), hijo de Pedro Enríquez y de Ú rsula Ruiz. ${ }^{104}$

Laureano heredó siete pares de casas que había en el solar comprado por su padre al arquitecto Alonso de Torres Fornicedo, en la calle que iba del C olegio de las Doncellas al Convento de Regina, y que habían sido valuadas por Cristóbal de M edina Vargas en io I25 pesos. ${ }^{105}$

Efraín Castro apunta que Laureano Ramírez de Contreras murió entre el is de octubre de 1686 - en que otorgó testamento- y el 23 de diciembre de ese mismo año, en que su esposa figura ya como viuda, en la partición de la herencia de Pedro Ramírez, el viejo. ${ }^{106}$ En efecto, murió el 23 de octubre de ese año de i686. D e acuerdo con la partida de defunción testó ante Antonio

\footnotetext{
99. ASM, Libro g de matrimonios de españoles, I667-I672, f. 38. Ioo. ASM , Libro Io de matrimonios de españoles, I672-I680, f. I2V. IOI. ASM, Libro 21 de bautismos de españoles, $1663-1667$, f. $93 \mathrm{~V}$. I02. 3 de junio de I680. ASM, Libro 26 de bautismos de españoles, I679-I682, f. IIo. I03. ASM , Libro 27 de bautismos de españoles, I682-I685, fS. $25 \mathrm{~V}$ y 82, respectivamente. I04. ASM , Libro 28 de bautismos de españoles, I685-1688, f. 47.

I05. Torres Fornicedo había comprado el solar en ı670, en 550 pesos, al juzgado de capellanías. Vid. G lorinela G onzález Franco, M aría del Carmen O Ivera Calvo y Ana Eugenia Reyes, Artistas y artesanos a través de fuentes documentales, vol. I, M éxico, Instituto N acional de Antropología e H istoria, 1994, pp. 303 y 340. Ante el notario núm. 196, Pedro Deza y Ulloa, 039 , p. 7. Io6. 0 p. cit., p. 36.
} 
de Anaya, "escribano real y de provincia", el is del mismo mes y año, dejando por albacea y tenedora de bienes a su esposa; como albaceas al capitán Juan Rodríguez de la M uela (su suegro o cuñado de parte de su primera mujer), y a su hermano el bachiller Agustín Ramírez; y por herederos a sus hijos. Ahí mismo se asienta que "no dejó misas", que vivía "en la esquina de Santa Catherina de Sena", y que fue enterrado en la iglesia de N uestra Señora de EI Carmen, ${ }^{107}$ al igual que su padre y hermanos.

Tras haber desbrozado, abonado y empezado a cosechar con noticias útiles la parcela correspondiente al perfil biográfico de los miembros de esta familia, quisiera aprovechar la ocasión para verter algunas consideraciones en relación con la personalidad artística, la actividad y obra de los mismos, y en particular para entretejer unas reflexiones en torno a la actuación del pintor de la familia: Pedro Ramírez, el mozo.

En lo que toca a Diego Ramírez, sabemos que, a finales de 1622 y junto con otros artistas (Juan de Arrúe, G aspar de Angulo, Juan de C ejalvo y Bartolomé de $\mathrm{M}$ endoza) participó en la fábrica del retablo mayor del convento de San Jerónimo, y que en i627 se comprometió a hacer el retablo principal de la iglesia del santuario de la V irgen de Guadalupe. D e sus posibles discípulos o colaboradores nada sabemos, pero tal vez le corresponda el dato de Antonio de la Barrera, español de 25 años y "oficial de carpintero" que estaba en el taller del maestro carpintero D iego Ramírez, en agosto de i633. ${ }^{\text {I08 }}$

Por otra parte, aclarado el hecho de que se trata de dos Pedro Ramírez, y de que el padre fue el escultor, ensamblador y arquitecto, y el hijo el pintor, es posible descargar al segundo de las obras de su padre, que hasta hace poco se creían suyas.

Entre las obras del padre podemos citar el retablo del altar mayor de la Iglesia del Hospital de San Lázaro, trabajo por el que cobró i 500 pesos en I64I; el proyecto "de cuatro rostros" que presentó en i656 para el sagrario del

I07. ASM , Libro 2 de defunciones de españoles, I68I-I686, f. 316.

I08. Vid. Raquel Pineda, Catálogos de D ocumentos de Arte, 4. Archivo G eneral de la N ación. M éxico. Ramo: M atrimonios. Primera parte, M éxico, U niversidad N acional Autónoma de $M$ é xico, Instituto de Investigaciones Estéticas, I984; ficha or83, p. 23. 
altar mayor de la Catedral M etropolitana (trabajo para el que también presentó proyecto el platero $M$ iguel de $H$ ena, y del que se ignora quién ganó 0 si ningún proyecto se aprobó, pues no sería hasta i673 cuando Antonio M aldonado, Juan $\mathrm{M}$ ontero y Pedro $\mathrm{M}$ aldonado habrían de ejecutar dicho altar). En febrero de i66o contrató el retablo mayor de la iglesia del convento de Santa Clara, el cual se comprometió a entregar en enero de i66r a un costo de 9 mil pesos. En i622 concertó la fábrica de un retablo para el entierro de los herederos del patrono Andrés Arias Tenorio en la misma iglesia de Santa Clara, que estaría en el crucero y para el cual se mencionan diez lienzos sobre tela, más otras cuatro sobre tabla para el banco; cobraría dos mil pesos y lo debería entregar en ocho meses. En julio de ese mismo año de i662 contrató la hechura del retablo mayor de la antigua iglesia de San Francisco, que debería entregar en i8 meses, esto es, para octubre de i663; cobraría i4 mil pesos y se quedaría con la retacería del retablo anterior que tenía que desmontar y del cual se querían conservar sólo las pinturas del "afamado Basilio". Fray Agustín de Vetancourt, quien lo llama "insigne arquitecto", dice que también fabricó la escalera de San Buenaventura y la portería del convento franciscano. En i666 ejecutó dos piras o túmulos funerarios que se erigieron en M éxico en honor de Felipe IV. D e estos monumentos hablaremos más adelante.

Respecto de Pedro Ramírez, hijo, no está de más recordar que se trata de un artista que ha tiempo que ocupa un lugar destacado en el desarrollo de la pintura colonial, hasta el punto de que se le ha venido considerando como uno de los principales representantes de la llamada fase claroscurista en la N ueva España. La elevada calidad de algunas de sus obras hizo que se pensara que era español y que, por lo mismo, su formación debió haberse verificado a la sombra del mismísimo Zurbarán, lo cual no fue obstáculo para que también se afirmara que, ya en M éxico, se convirtiera en "discípulo" o seguidor del sevillano Sebastián López de Arteaga. La idea de que era español ya ha quedado descartada. Ahora, a la luz de la noticia de que nació en M éxico, y, en consecuencia, de que aquí debió llevar a cabo su aprendizaje, habrá que replantear el problema de su formación pictórica.

A este respecto, conviene recordar que también se ha convertido en un lugar común el consignar al sevillano Sebastián López de Arteaga, junto con José Juárez, Pedro Ramírez y Baltasar de Echave Rioja, como los mejores exponentes de la pintura de cepa zurbaranesca, de fuertes contrastes lumínicos que se estilaran en M éxico a mediados del siglo XVII, y a los tres últimos co- 
DOI: http://dx.doi.org/10.22201/iie.18703062e.2000.77.1948

92

ROGELIO RUIZ GOMAR

mo "discípulos" del primero. $Y$ aunque poco a poco se ha ido minimizando la supuesta gran influencia de Francisco de Zurbarán en todo esto, no podemos menos que reconocer que en la introducción al medio novohispano de dicha modalidad - proceso que, la verdad, dista bastante de estar debidamente aclarado- , mucho contribuyó, sí, el paso del mencionado Sebastián de Arteaga a la N ueva España, pero también la llegada a M éxico de obras de artistas de la escuela sevillana, entre las que se contarían al gunas de Zurbarán o, mejor aún, de su taller, así como del amplio círculo de los seguidores de su estilo, o de otros artistas menos conocidos que compartían notas similares, a las que abusivamente hemos designado, sin más, como "zurbaranescas", y que en realidad formaban parte del lenguaje pictórico común a casi todos los artistas que estaban activos en el primer tercio del siglo XvII en Sevilla, incluyendo al joven D iego Velázquez.

Restringiéndonos al caso de Arteaga y Pedro Ramírez, futuras investigaciones vendrán a aclarar el punto de si éste pudo o no ser discípulo de aquél. Por ahora convendría retener, tan sólo, que más allá del empleo de una serie de notas comunes - y sobre las que hemos exagerado al suponer su efecto-, atendiendo exclusivamente al manejo de las fechas, es muy escasa la posibilidad de que Ramírez hubiese alcanzado a conocer y tratar a Arteaga, justo cuando se disponía a iniciar su aprendizaje artístico. Y es que, si bien es cierto que Arteaga llegó a la N ueva España alrededor del año de ı640, cuando Ramírez contaba con tan sólo dos años de edad, su muerte ocurrió en I652, año para el cual ya Ramírez tendría doce años. Así, aunque difícil, no se puede descartar del todo que el sevillano hubiese tenido al go que ver en su formación. Con todo, convendría tener presente que otros varios y buenos pintores estaban activos por ese entonces, tanto en la ciudad de M éxico como en la de Puebla, sin duda los dos centros pictóricos novohispanos más importantes a mediados de esa centuria. Por mencionar a algunos de los más importantes, habría que recordar a José Juárez, al licenciado Juan Sal guero y a Sebastián López Dávalos, en la ciudad de M éxico, y a Diego de Borgraf, Gaspar Conrado y Rodrigo de la Piedra, así como a los desconocidos Pedro de Vergara, Pedro Chacón y Pedro de Venavides, en la de Puebla. ${ }^{109}$ La nove-

ı09. Salvo Rodrigo de la Piedra, los demás están mencionados en la elaboración de pinturas para los retablos de varias capillas que se iban a hacer en la catedral angelopolitana en I648. Vid. Francisco Pérez de Salazar, H istoria de la pintura en Puebla, M éxico, U niversidad N acional Autónoma de M éxico, 1963, pp. I66-i68. 
dad de incluir aquí a artistas activos en el medio pictórico poblano obedece a que, como hemos planteado, en él pudo pasar Ramírez parte de su adolescencia y primeros años de vida profesional.

Pero volviendo al punto que venimos considerando, convendría precisar que ha sido un error el considerar a José Juárez, Echave Rioja y Pedro Ramírez los supuestos discípulos de Arteaga, como pertenecientes a una misma generación. Ya hemos visto que esto vale para los últimos dos, pues nacieron en 1632 y i638, respectivamente, pero no para José Juárez, quien por haber nacido en i6r7 era casi veinte años mayor que Pedro Ramírez. Así las cosas, y sin poder aún afirmar nada, está claro que va cobrando fuerza la posibilidad de que Juárez - y no Arteaga- hubiese sido el maestro de los otros dos, o la de que, al menos, hubiese tenido algo que ver en la formación de ambos. Relación casi confirmada para el caso de Echave Rioja - pues en un determinado momento parece que éste trabajaba en su taller- ${ }^{\text {IIo }}$ y bastante plausible para el caso de Ramírez, cuanto más si recordamos que Juárez no era ajeno a la familia Ramírez, pues, como vimos, en abril de i644 había sido padrino de bautismo de un hijo de la hermana de Pedro Ramírez el viejo, ${ }^{\text {III }}$ fecha para la cual el futuro pintor contaba con casi seis años.

Para desechar o fundamentar esta sospecha, habrá que esperar a que se reúna y estudie con detenimiento la obra de Pedro Ramírez, pues en el estado actual de los conocimientos no se puede ir más allá de simples apreciaciones en torno al punto de si hay o no huellas del lenguaje pictórico de José Juárez en su producción.

La actividad de Pedro Ramírez de C ontreras abarca alrededor de 30 años. Si nació en I638 pudo comenzar a trabajar desde los últimos años de la década de los cincuentas - si bien es más creíble que principiara en la de los sesentas- y lo siguió haciendo hasta su muerte, en 1679.

Sin ser un prolífico autor, conocemos una buena cantidad de obras suyas. Empecemos por recordar las escasas pinturas a las que se les asigna alguna fecha y que han llegado a nosotros.

IIo. En el testamento que hizo en I66I, poco antes de morir, José J uárez nos deja saber que Echave le debía algún dinero y que éste se lo estaba pagando con obra. Vid. Efraín Castro M orales, "El testamento de J osé J uárez", en Boletín de M onumentos H istóricos, núm. 5, M éxico, Instituto N acional de Antropología e H istoria, I98ı, p. 9.

III. Vid. infra nota io. 


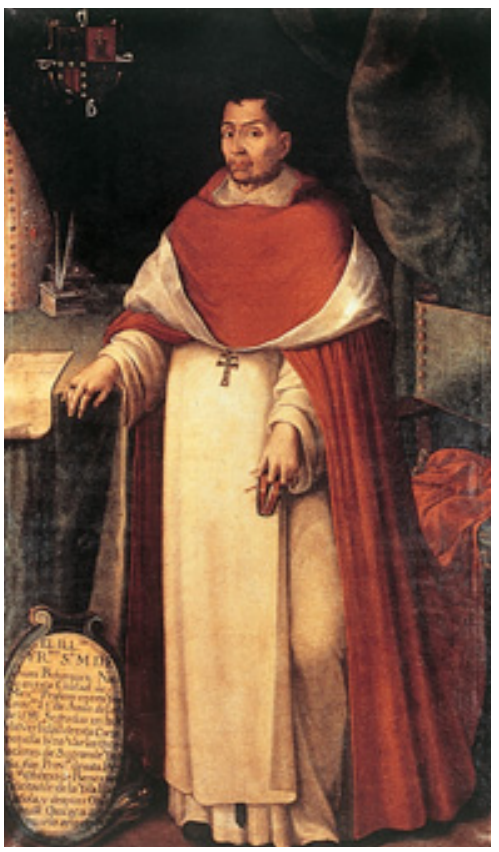

Figura i. Pedro Ramírez, Retrato del obispo J uan Bohórquez, óleo sobre tela, M useo N acional del Virreinato, Tepotzotlán, Estado de M éxico. Foto: Archivo Fotográfico IIE-UNAM .

En este sentido, se ha venido considerando como su obra más temprana el retrato que hiciera del 0 bispo Juan Bohórquez que se conserva en el M useo Nacional del Virreinato. La fecha que se le asigna es la de ${ }_{5553}$, que a todas luces resulta insostenible, habida cuenta de que para entonces nuestro artista contaba apenas con is años. Dicha fecha no sólo se ha leído mal - en realidad es i633- , sino que corresponde a la del año de la muerte del prelado de $\mathrm{O}$ axaca. $\mathrm{H}$ abrá, pues, que descartar de la lista de las obras fechadas este retrato. ${ }^{\text {II2 }}$

Del mismo modo, la mayor parte de los autores ha venido aceptando la fecha de 1656 para el hermoso lienzo de Jesús servido por los ángeles (Parroquia

II2. Pese a que Diego Angulo Íñiguez sí leyó correctamente la fecha, insiste indebidamente en hacer arrancar su actividad desde dicho año de ${ }_{1633}$ - año para el que aún ni había nacido- , y la lleva hasta i678 - que corresponde a la fecha de su obra más tardía- , extendiendo dicha actividad por 55 años, lo que ya de por sí se antoja algo difícil de aceptar. H istoria del arte hispanoamericano, Barcelona, Salvat, I95I, t. II, p. 4I6. 


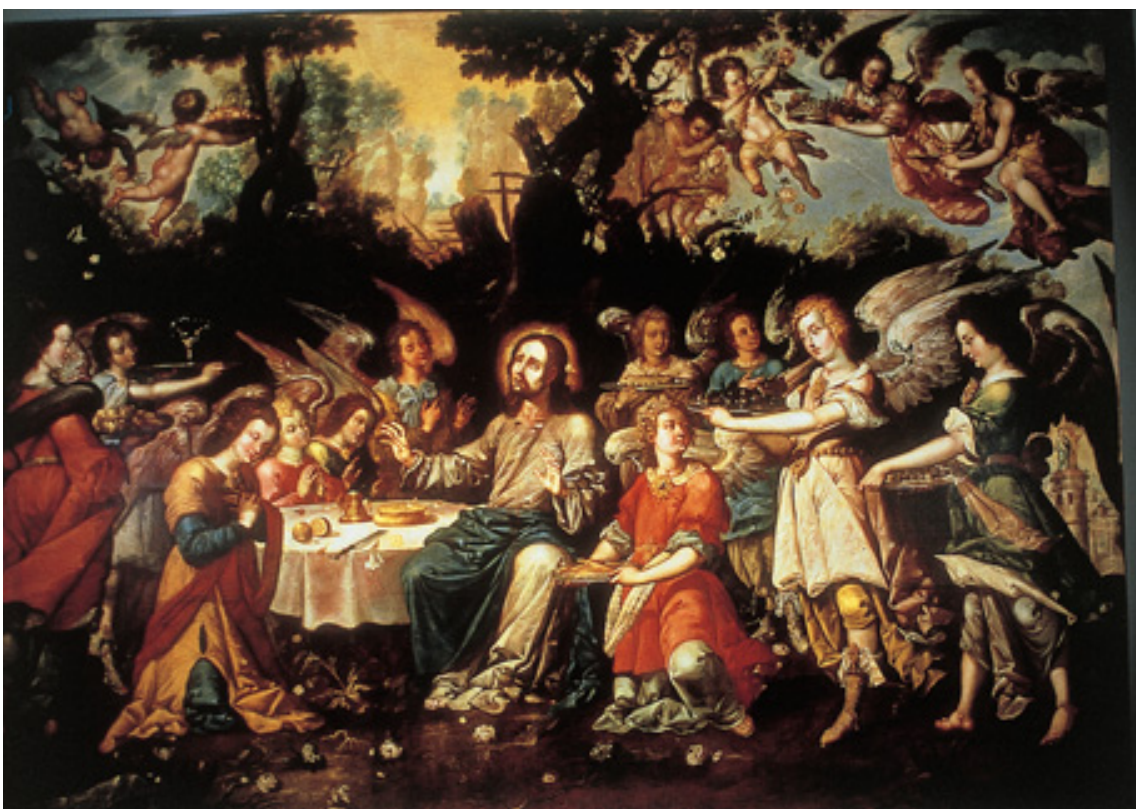

Figura 2. Pedro Ramírez, Jesús servido por los ángeles, óleo sobre tela, Parroquia de San M iguel, M éxico, D.F. Foto: Archivo Fotográfico IIE-UNAM.

de San M iguel, M éxico, D.F.), "r3 obra que exhibe un vigoroso grupo de atractivos ángeles adolescentes y un buen paisaje logrado en armonías azulosas y doradas, que al decir de Toussaint resultaba inédito para la pintura novohispana, lo que lo llevó a proponer que quizá fue Ramírez quien trasmitió este gusto a los artistas que poco después se deleitarían en él, como Juan C orrea y Cristóbal de Villalpando. ${ }^{114} \mathrm{M}$ ientras no se tenía conocimiento del año en que había nacido, nadie había reparado en lo impropio de la fecha asigna-

II3. Los únicos que le asignaron la fecha de ı670 fueron Xavier Villaurrutia (EI arte en M é xico. Pintura colonial, núm. 4, M éxico, Cervecería Cuauhtémoc), y Abelardo Carrillo y Gariel, T écnica de la pintura de N ueva España, M éxico, U niversidad N acional Autónoma de M éxico, 1946, p. I64.

II4. T oussaint, Pintura colonial... , p. I07. Véase también Clara Bargellini, "J esús servido por los ángeles", en Arte y mística de barroco, M éxico, U niversidad N acional Autónoma de M éxico, Consejo N acional para la Cultura y las Artes, D epartamento del Distrito Federal, I994, pp. 56-58. 
DOI: http://dx.doi.org/10.22201/iie.18703062e.2000.77.1948

96

ROGELIO RUIZ GOMAR

da a este cuadro; pero ahora las cosas han cambiado, hasta el punto de que, en el mejor de los casos, se antoja sospechosa. Y es que si la lectura de la dicha fecha de 1656 es correcta, resultaría que estamos no sólo frente a su obra más temprana, sino a la obra de un precoz maestro, pues para entonces $\mathrm{R}$ amírez apenas contaría con I8 años. ${ }^{\text {II }}$

Al decir de Xavier M oyssén, es de i67o la Liberación de san Pedro que localizó G onzalo O bregón en una colección particular, obra que puede entenderse como una réplica o segunda versión del espléndido cuadro del mismo tema que se guarda en el M useo $\mathrm{N}$ acional del Virreinato, y del que nos ocuparemos más adelante. ${ }^{\mathrm{II}}$

La fecha de 1673 se lee fácilmente en uno de los dos grandes lienzos que se custodian en la $C$ atedral de Guatemala y que representan El carro triunfal de la I glesia y La eucaristía y los sacrificios paganos. ${ }^{117}$ Ambos cuadros encierran el interés de ser los primeros que repiten en el ámbito hispanoamericano estas dos composiciones, las cuales formaban parte de la serie eucarística cuyos 17 diseños fueron realizados por el genial Pedro Pablo Rubens y usados como modelos de la tapicería que mandara hacer la emperatriz Isabel Clara Eugenia y regalara al monasterio carmelita de las D escalzas Reales de $\mathrm{M}$ adrid. ${ }^{\text {I8 }}$ Pedro Ramírez siguió con tal fidelidad el tono triunfalista y propagandístico de dichas composiciones, que conoció a partir de los grabados que sobre aquéllas hiciera Schelte a Bolswert, que no sólo incluyó los enmarcamientos arquitectónicos - necesarios para un tapiz pero no para una pintura

II5. D icha fecha es la que leyó $M$ anuel Toussaint; sin embargo, resulta muy significativo apuntar que hoy en día ya no existe, pues no se recuperó en la reciente restauración a que el cuadro fue sometido. ¿Se eliminó por considerarla una repetición? Pero aun así, ¿por quién, cuándo y para qué fue añadida? Preguntas que por ahora desafortunadamente quedan sin respuesta.

II6. Véase la nota i6 que puso al capítulo XVII de la Pintura colonial en M éxico, de M anuel T oussaint ( $M$ éxico, U niversidad N acional Autónoma de M éxico, Instituto de Investigaciones Estéticas, 1965, p. 257). Este cuadro es el que aparece reproducido en la lámina a color número xv en la ia. y za. ediciones de esta obra, pero ya no en la za.

II7. Este par de cuadros fue dado a conocer por H einrich Berlin, "Pintura colonial mexicana en G uatemala", en Anales de la Sociedad de G eografía e H istoria de Guatemala, t. 26; Guatemala, 1952, pp. I2I-I22. Tal vez por una confusión, Xavier M oyssén menciona la fecha de I677, véase Pintura... , op. cit. n. I6, p. 258.

II8. Vid. Rogelio Ruiz Gomar, "Rubens en la pintura novohispana de mediados del siglo XVII", en Anales del Instituto de Investigaciones Estéticas, vol. XIII, núms. 50-5I, M éxico, I982, pp. $95-97$. 


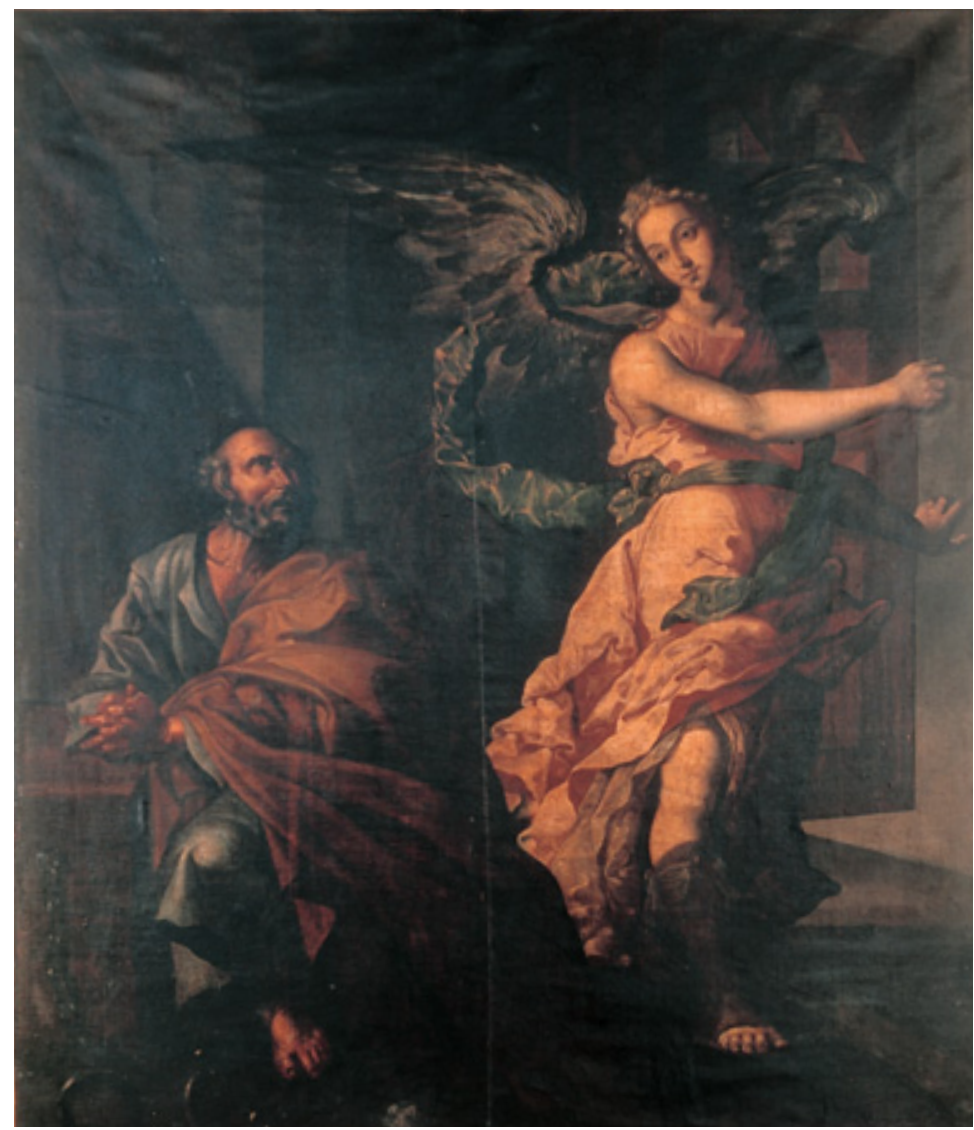

Figura 3. Pedro Ramírez, La liberación de san Pedro, óleo sobre tela, M useo $\mathrm{N}$ acional del Virreinato, T epotzotlán, Estado de M éxico. Foto: Archivo Fotográfico IIE-UNAM.

que contaría con su propio marco- , sino que se atrevió a dejar los pechos desnudos de al gunas figuras femeninas, detalle que a nadie sorprende dentro de la obra de Rubens, pero que para el púdico medio americano se antoja atrevido. ${ }^{\text {II }}$

II9. Vid. Rogelio Ruiz G omar, "T riunfo de la Eucaristía” y "T riunfo de la Eucaristía sobre los sacrificios paganos", en M éxico en el mundo de las colecciones de arte: N ueva España $I$, M é xico, Azabache, 1994, pp. 228-231. 
De i678 - y no de i658 como afirmara Toussaint- es el cuadro de La flagelacion de Cristo que se exhibe en el Museo Regional de Guadalajara del Instituto $\mathrm{N}$ acional de Antropología e Historia, en el que repetiría, con el añadido de dos sayones, la composición que ya había usado para el cuadro del mismo tema que forma parte del retablo principal de la capilla de la Soledad, en la Catedral de M éxico, del que hablaremos más adelante. El cuadro de Guadalajara presenta el interés, además, de ser la última obra conocida salida de su pincel, ya que está fechado un año antes de su muerte.

A las obras anteriores habrá que agregar el trabajo que, documentado en mayo del año de i67I, recoge Efraín C astro M orales y que, por desgracia, no ha llegado a nosotros. El artista se comprometía a remozar el altar que tenía en su entierro el capitán Francisco Tausedo de Brito y su mujer Josefa G odoy y Valdivia, en la iglesia de San Pedro y San Pablo. Dicho trabajo - otorgado en la hacienda de San N icolás, en la jurisdicción del pueblo de Ixtapalapaconsistiría en agregar otra grada de cantera de chiluca y recimentar la base - para lo cual debía desarmar y luego volver a armar el retablo- , así como en llenar todo el cuerpo de la pared en la que éste se arrimaba con "cuatro lienzos de pintura al óleo con sus marcos de madera de ayacahuite, labrados con sus agallones dorados con oro de color y perfilados en negro, de los pasos de la Pasión de C risto, que eligiere el padre Florián Alberto, sacristán mayor de la iglesia de dicho colegio". Asimismo, debería picar y reponer el yeso del hueco redondo de la ventana encima del altar, y pintarlo "de oro y azul, al temple y perfiles negros", y colocar sobre dicha ventana "un lienzo... al óleo con dos ángeles desnudos, con la corona de espinas en las manos, con su marco" (disposiciones iguales a las del anterior), y, flanqueando al retablo desde el guardapolvo, otros "ocho ángeles, pintados al óleo, desnudos, con las insignias en las manos de la Pasión", debidamente enmarcados. Todos los dichos lienzos habían de estar imprimados "con aceite de linaza en bramante crudo, de vara y tercio de ancho". El plazo para terminar el trabajo era de cuatro meses y recibiría 750 pesos, incluyendo la nueva grada de cantera y el blanqueado de muros y arco, así como los materiales y el pago de los oficiales. ${ }^{120}$ Por incluir labores de pintura se entiende que se le conceda al hijo este trabajo, pero, al menos por las fechas, y por incluir también tareas diferentes,

I20. Archivo General de N otarías de la Ciudad de M éxico, notaría 379 (Baltasar M orante), I67i; citado por Efraín Castro M orales, op. cit., pp. 22-24. 
no se puede descartar que se trate de un encargo hecho al padre y en el que, por supuesto, cabría aceptar la intervención de ambos.

El resto de su producción conocida es de heterogénea calidad y difícil de ubicar cronológicamente, al menos en el estado actual de los estudios.

Su obra más importante es, sin lugar a dudas, la espléndida tela de la Liberación de san Pedro del M useo N acional del Virreinato, indebidamente registrada desde Toussaint como Las lágrimas de san Pedro. El acendrado juego de luces y sombras, así como la factura recia y el manejo de los volúmenes que exhibe hicieron que se creyera obra del mismísimo Zurbarán. No fue hasta cuando apareció la firma "Ramírez", al estar limpiándolo José M oreno Villa, cuando se incorporó al catálogo del artista que nos ocupa. ${ }^{21}$

O bra, en verdad, impresionante por su calidad, pero que bien mirada resulta bastante menos "zurbaranesca" de lo que se ha venido sosteniendo. $\mathrm{N} \mathrm{i}$ los tipos de los personajes, ni la manera de plegar las telas, ni el modo de manejar los contrastes de luces y sombras, ni el planteamiento espacial tienen que ver con el lenguaje del gran maestro español. Acaso en las calidades de las telas - especialmente en las del san Pedro- se puede establecer una cierta similitud, pero aun en éstas hay marcadas diferencias. Cuadro en el que se pudiera decir que Ramírez llevó hasta sus últimas posibilidades el equilibrio plástico que deriva del empleo de una eficaz dialéctica pictórica: a una figura semisentada opone otra de pie; a una quieta y rotunda, otra dinámica y ligera; a una con señales de vejez, otra plena de lozanía; y todo ello en dos figuras que aparecen dispuestas hacia afuera, en direcciones contrarias, pero que se complementan al quedar con las cabezas giradas hacia el centro.

En la capilla de la Virgen del Rosario en la iglesia del ex convento dominicano de Azcapotzalco se conservan, aunque en mal estado, dos lienzos alargados en sentido vertical, de gran belleza, en los que está representado dos veces el arcángel san M iguel, en compañía de la Inmaculada, la Asunción y las santas Teresa de Ávila y Rosa de Lima. El hecho de que aparezca la santa limeña permite inferir al maestro J orge Alberto $M$ anrique que se trata de una obra difícilmente anterior al año de i670, puesto que Santa Rosa fue beatifi-

I2I. Este cuadro lo encontró Toussaint en el "Palacio Arzobispal" de T acubaya y por su extraordinaria calidad se determinó incorporarlo a las colecciones del Tesoro de la Catedral de M éxico que se exhibía en el Ilamado "M useo de Arte Religioso", sitio de donde pasó en I964 a T epotzotlán. Vid. Pintura novohi spana. M useo N acional del Virreinato, t. I, M éxico, Asociación de Amigos del M useo N acional del Virreinato, 1992, PI/or35, p. I33. 


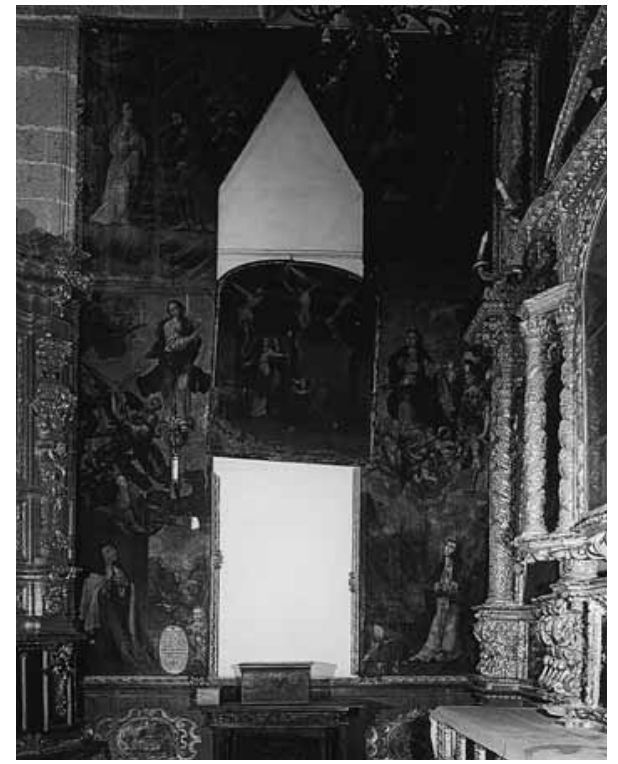

Figura 4. Vista de las pinturas de Pedro Ramírez en la C apilla del Rosario, en Azcapotzalco. Foto: Archivo Fotográfico IIE-UNAM .

cada en I668 y canonizada en I671. ${ }^{\mathrm{I22}}$ Sea como fuere, lo cierto es que se trata de una de las más tempranas representaciones de la santa limeña en M éxico. Con buen juicio el citado autor asevera que estos cuadros son "hijos de la madurez", habida cuenta de que ya no muestran sus exageraciones anteriores (sea el manejo de contrastes lumínicos o la prodigalidad formal), sino sobriedad y equilibrio.

Sobre estos cuadros cabría agregar que, hacia mediados del año de 1994 - incomprensiblemente al parecer nadie se percató de ello-, del lienzo en el que está representada santa Teresa fue recortado el rostro del niño que aparecía en la parte baja sosteniendo la cartela: absurda, reprobable y torpe mutilación que mucho nos debe doler a todos, por cuanto que era uno de los pocos casos, en nuestra pintura colonial, del "niño donante". Su presencia puede entenderse como el resultado de una especie de modestia de quien pagaba el cuadro, pero que, interesado en que quedase un testimonio suyo, consintió en que fuera su hijo quien perdurase. ${ }^{123} \mathrm{D}$ e ese niño $M$ anri-

I22. Jorge Alberto M anrique, Los dominicos y Azcapotzalco, Jalapa, U niversidad V eracruzana, 1963, p. 75 .

I23. I bidem. O tro ejemplo sería el niño, hijo del tal Alonso Gómez, que figura en el cuadro 
Figura 5. Pedro Ramírez, detalle del niño en uno de los lienzos de la Capilla del Rosario en Azcapotzalco, antes de su mutilación. Foto: Archivo Fotográfico IIE-Un AM.

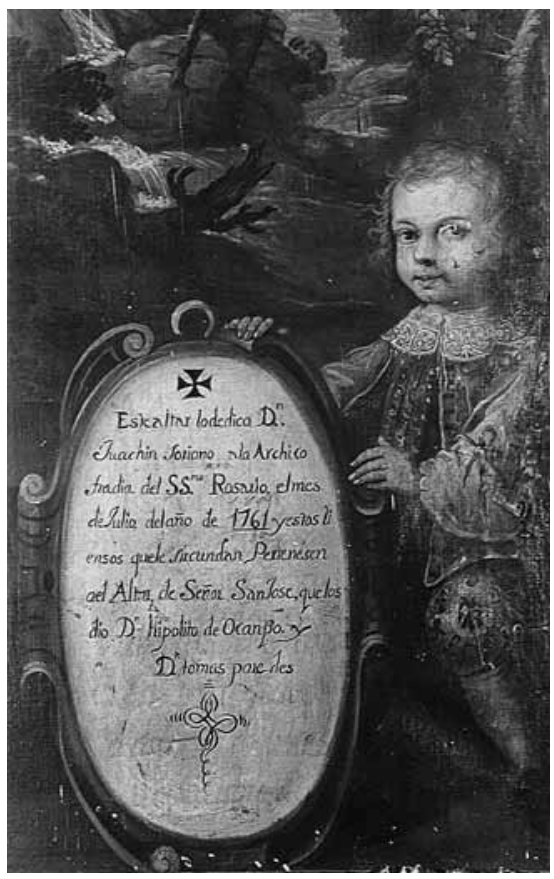

que había expresado que "tendrá unos dos años y se ve incómodo en esas ropas tiesas, de raso recamado de oro, con su gran cuello de encaje almidonado"; y del que agregó que, pese a que se le ve "asustado" por tener que quedarse inmóvil frente a un extraño, "es uno de los niños más encantadores, con su cara extrañada y un poco tonta, de toda nuestra pintura colonial". I24

Por otro lado, a excepción del lienzo de la Ú Itima cena, al centro, que está firmado por José M aría Vázquez, son igualmente suyas todas las pinturas que luce el retablo principal de la capilla de La Soledad en la Catedral de M éxico con escenas alusivas a la Pasión de Cristo: un San Pedro y una M agdalena, en la predela; La oración del huerto y La flagelación en el primer cuerpo; un Ecce

de J osé J uárez de la Visita de la Virgen y el $\mathrm{N}$ iño a san Francisco, que pertenecía a la T ercera O rden de San Francisco y que, tras exhibirse en la Pinacoteca Virreinal, actualmente forma parte del M useo N acional de Arte (MUNAL) de la ciudad de M éxico.

I24. 0 p. cit., p. 79. 
DOI: http://dx.doi.org/10.22201/iie.18703062e.2000.77.1948

IO2

ROGELIO RUIZ GOMAR

H omo y el Encuentro con lasmujeres, en el segundo registro; y en el remate un Padre eterno, en óvalo, amén de un Rey de burlas y un Ángel con el cuerpo de Cristo, conjunto de obras que exhiben corrección en el dibujo, atinada distribución de las figuras, buenas anatomías y un animoso colorido. Q uizá también sea suya la Virgen de la Soledad del centro, que, pese a los repintes que exhibe, muestra notas propias de su estilo, especialmente por lo que concierneal modo de plegar las cortinas a los lados. ${ }^{125}$

En la iglesia parroquial de Lerma, Estado de M éxico, se registra de su mano una Virgen de la Antigua. También en este caso habría que llamar la atención sobre el hecho de que se trata de una de las primeras representaciones - si no es que la más temprana - de esta advocación mariana en la N ueva España que procedía del mundo devocional sevillano.

D e la buena estima que alcanzó su pincel en la época da cuenta el que en la catedral de la actual ciudad de Guatemala se guarde una buena porción de obras suyas llegadas a ese destino seguramente a lomo de mula. A los dos grandes lienzos ya mencionados con las alegorías eucarísticas, hay que sumar los trece lienzos que conforman la interesante serie con escenas de la "Vida de la Virgen", con los siguientes pasajes: N acimiento de la Virgen, Presentación de la Virgen al templo, D esposorios, La anunciación, Adoración de los pastores, Adoración de los reyes, Presentación del niño al templo, H uida a Egipto, Jesús entre los doctores, Tránsito de san José, Pentecostés, Asunción de la Virgen, e Inmaculada Concepción, ${ }^{126}$ obras de calidad dispar, pues en tanto que al gunas exhiben cierta sequedad, otras encierran trozos de muy buena factura. En general se encuentran en un regular estado de conservación, si bien algunas pinturas de la serie exhiben deterioros y repintes. Entre las obras que muestran aceptable factura y resultan dignas de atención se encuentra la de $L a$ anunciación, en que resalta que la cabellera del arcángel san $G$ abriel no sea rubia ni tan ensortijada como se acostumbraba en su tiempo; o la de La adoración de los reyes, que repite el esquema del pintor flamenco G erard Seghers - usado luego también por Juan Correa - con el rey mago vuelto

I25. Vid. N elly Sigaut, "C apilla de N uestra Señora de la Soledad", en Catedral de M éxico. Patrimonio artístico y cultural, M éxico, SEDESOL, I986.

I26. El primero en referirse a esta serie de lienzos fue Diego Angulo, op. cit., p. 4I6. Véase también Rogelio Ruiz G omar, "Adoración de los pastores", "Presentación de Jesús al templo" e "Inmaculada C oncepción", en M éxico en el mundo de las colecciones de arte: N ueva España $I$, M éxico, Azabache, 1994, pp. 221-223. 


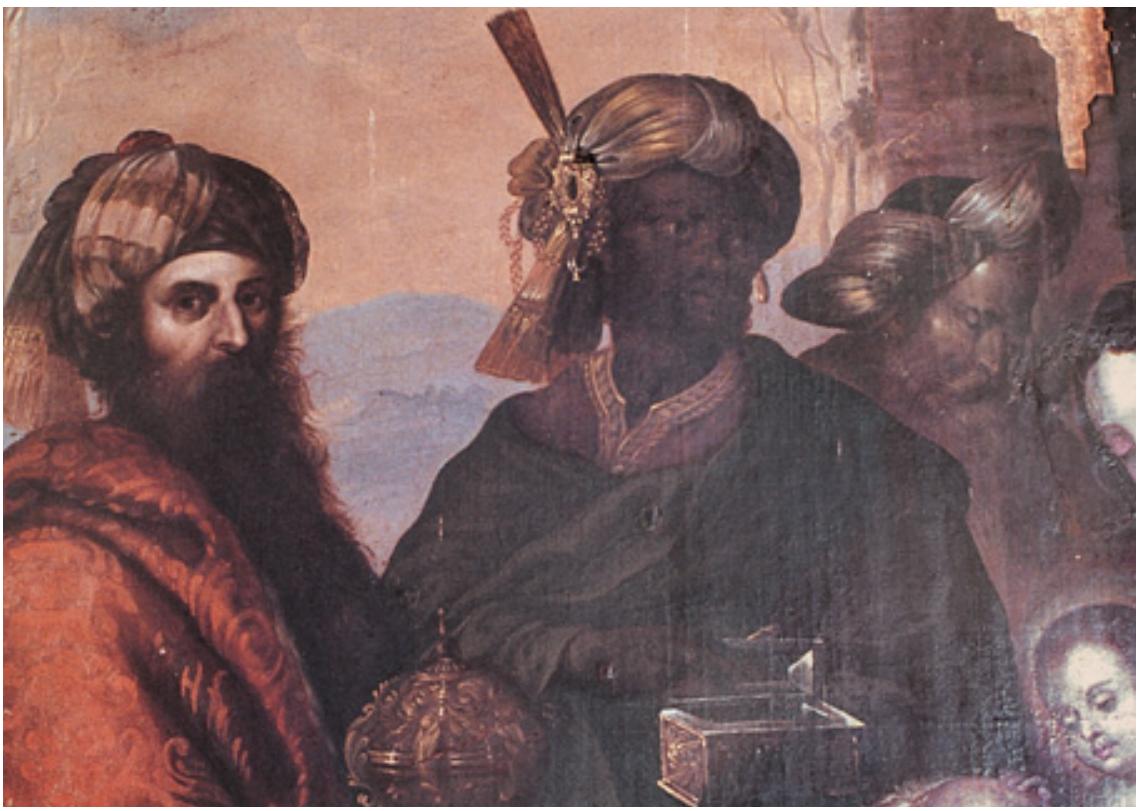

Figura 6. Pedro Ramírez, detalle del cuadro de La adoración de los Reyes, óleo sobre tela, C atedral de Guadalajara. Foto: Amada M artínez, Archivo Fotográfico IIE-U N AM .

hacia el espectador en un extremo. En varias de ellas - Nacimiento de la Virgen, Presentación del niño al templo- Ramírez echó mano del expediente de sugerir los diferentes planos de profundidad, no por el uso de la perspectiva, sino mediante el manejo de zonas con distinta iluminación, manejo claroscurista asociado comúnmente con Zurbarán, pero que en realidad está en el ambiente pictórico sevillano de la primera mitad del siglo XVII, y que fue bien asimilado por los pintores novohispanos de la segunda mitad de esa centuria. En varios de estos cuadros el pintor echó mano de soluciones pictóricas que se aprecian en otras obras suyas, como puede ser el gusto por incluir rostros de perfil, con el mentón algo pronunciado; la construcción de las manos mediante eficaces brillos en los nudillos o las falanges; el empleo de una rica paleta de colores brillantes y contrastados, o el efectista plegado de las telas.

Por otra parte, de entre los cuadros de dicha serie quiero destacar el que representa a la Purísima Concepción, habida cuenta de que es el primero que copia la composición del cuadro, ahora perdido, pero concedido al pintor es- 
IO4

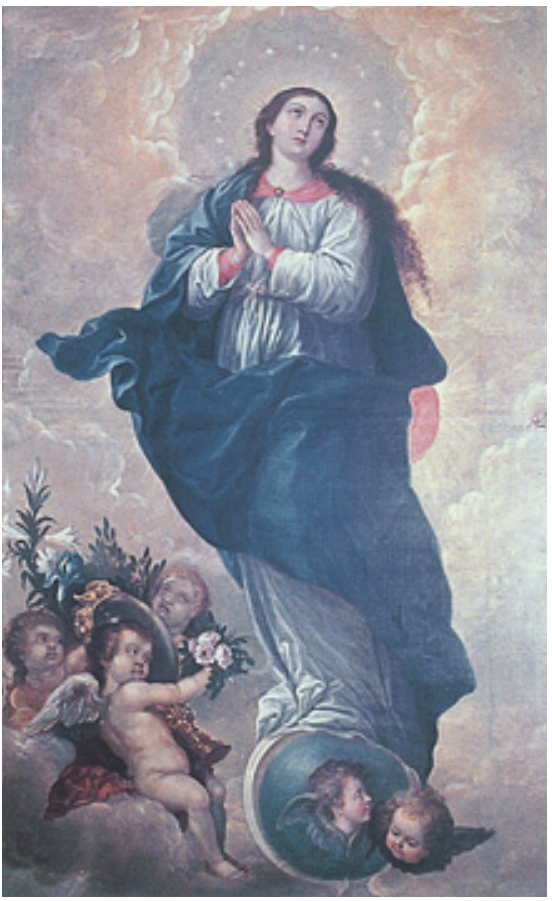

ROGELIO RUIZ GOMAR

Figura 7. Pedro Ramírez, La Purísima Concepción, óleo sobre tela, Catedral de Guatemala. Foto: Amada M artínez, Archivo Fotográfico IIE-UNAM .

pañol Francisco Rizi, y que debió de existir en la Catedral de Puebla. ${ }^{127}$ D e la estima y buena fortuna que desde el principio gozó esta obra, da cuenta el que pronto sirviera de modelo a los pintores novohispanos. A la versión de Ramírez, que es la primera, siguieron las de D iego de Borgraf - quien la copió por lo menos en dos ocasiones- y las de Cristóbal de Villalpando. ${ }^{128}$

I27. D e este pintor hubo, al parecer, más obras en la C atedral de Puebla, como por ejemplo una copia de la $V$ irgen del Sagrario de la $C$ atedral de T oledo, y que supuestamente envió Rizi en 1652 a la catedral angelopolitana. Vid. Diego Angulo Íñiguez, "Francisco Rizi. Cuadros re ligiosos posteriores a i670 y sin fechar", en Archivo Español de Arte, núm. I38, M adrid, I962, pp. 95-I22. Junto con Carreño de $M$ iranda y H errera el M ozo, Rizi desempeñó un importante papel en la renovación de la pintura madrileña de mediados del siglo XVII, escuela que, por razones y caminos todavía sin estudiar, habría de estar presente en el medio pictórico novohispano, particularmente en el de la ciudad de Puebla.

I28. U no de los cuadros de Borgraf y el de Villal pando se conservan en la Antesala y Sala de los $\mathrm{G}$ obelinos de la Catedral de Puebla. El otro de Borgraf pertenece a las colecciones del M useo de la U niversidad Autónoma de Puebla. D e nueva cuenta V illalpando recurrió a ese mo- 
Lienzo que ha llegado hasta nosotros recortado y que por lo mismo no ostenta rasgo de firma, pero que tradicionalmente se le ha atribuido, es el de la Adoración de los pastores, de considerables dimensiones, que formaba parte de la colección que hasta fines del año 2000 se custodiaba en la Pinacoteca Virreinal de San Diego, de la ciudad de M éxico, y ahora se ha trasladado al Museo Nacional de Arte. ${ }^{129}$ Se trata de una obra de aspecto algo duro pero con trozos de aceptable calidad; su interés pero también su sequedad provienen de la iluminación efectista que exhibe, y que deriva de sugerir que es el cuerpecillo del Niño Jesús la fuente que ilumina la escena, expediente del que sistemáticamente casi todos los pintores echaron mano al ocuparse de este tema. Así, aunque presenta importantes variantes, parece que Ramírez conoció la versión de José Juárez que se guarda hoy en día, y en muy mal estado de conservación, en el Museo de la Universidad Autónoma de Puebla, pues la recuerda mucho en la disposición y características de las figuras del grupo principal.

O tra obra suya, de la que sólo nos ha llegado la noticia de su existencia, es la Virgen del Rosario, propiedad del grabador Campa que se expuso en la

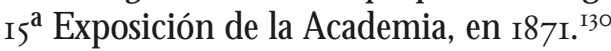

En el M useo Franz M ayer existe una tabla que representa el Nacimiento de la Virgen, de enérgico dibujo y encendido colorido, que se le atribuye; acaso sea la pintura que, con el mismo tema, registra Toussaint en el catálogo de la colección Barrón. ${ }^{131}$

O bra que hace años le atribuí a Ramírez y que sigo pensando puede ser suya es el vigoroso lienzo de la Coronación de espinas que cuelga a los pies del

delo, aunque invirtiéndolo, en la Purísima que incluyó en el cuadro que representa a San Juan Evangelista y a sor M aría de J esús de Ágreda con la visión de la Jerusalén cel estial que se exhibe en el M useo Regional de Guadalupe, en Zacatecas.

I29. Al decir de Xavier M oyssén este cuadro procede de la Biblioteca Cervantes de la ciudad de M éxico, en cuyo inventario ya figuraba como de Pedro Ramírez; vid. nota i6 al capítulo XvII del libro Pintura colonial en M éxico, de M anuel Toussaint, op. cit., p. 258. A mediados del siglo XIX ingresó a las galerías de la Academia de San C arlos, pues ya lo registra C outo en su D iálogo; de ahí pasó junto con toda la colección a la Pinacoteca Virreinal y por último, a finales del 2000, al M useo $\mathrm{N}$ acional de Arte.

I30. M edía 38 X 50 cm. C fr. M anuel Romero de T erreros, Catálogos de las exposiciones de la antigua Academia de San Carlos de M éxico (I850-I898), M éxico, U niversidad N acional Autónoma de M éxico, Instituto de Investigaciones Estéticas, I963, p. 426.

I3i. 0 p. cit., p. I07. Fue reproducido en el libro editado por Javier Pérez de Salazar La pintura mexicana, siglos XVI-XVII. Colecciones particulares, 1966. 
DOI: http://dx.doi.org/10.22201/iie.18703062e.2000.77.1948

106

ROGELIO RUIZ GOMAR

templo de La Profesa. ${ }^{132}$ Cuadro de buenas dimensiones, que sigue de cerca, aunque con ciertas variantes - desarrollo horizontal, eliminación de figuras, añadido de otras, etcétera - la composición del célebre cuadro de Anton van Dyck en el M useo del Prado, es una obra que presenta un eficaz y bien logrado manejo del claroscuro, un dibujo recio y el empleo de vigorosas musculaturas, notas que se avienen bastante bien con el lenguaje plástico que distingue a Pedro Ramírez.

Por un tiempo se barajó su nombre y el de Echave Rioja como el del posible autor de los hermosos medios puntos que se encuentran colgados a buena altura en diversas capillas de la $C$ atedral de M éxico. Empero, para últimas fechas se ha ido prefiriendo el nombre del segundo.

Q uisiera, por último, consignar dos obras que forman parte de la colección del M useo Nacional del Virreinato, en Tepotzotlán, que hasta ahora no se han relacionado con Ramírez, pero que por la cercanía que muestran con su lenguaje plástico, y a reserva de estudiarlas con más detenimiento, considero convendría tener presentes a la hora de conformar el catálogo de su producción. M e refiero a una bella Purísima con san I gnacio de Loyola que se encuentra en el vestíbulo de acceso a la C apilla D oméstica, y en la que se han querido ver acentos sevillanos. ${ }^{133}$ La otra obra es un lienzo - en realidad parece ser el resultado de unir dos o tres fragmentos- en el que se han representado las escenas de la O ración en el huerto y la Flagelación divididas por un elemento decorativo de claro acento rococó - razón por la cual se ha asignado al cuadro una fecha de mediados del siglo XVIII, pero que perfectamente pudo haber sido añadido- , y es que se trata de una obra cuyo lenguaje pictórico no sólo corresponde claramente a la centuria anterior, sino que, pese a las variantes que pudieran señalarse respecto a las versiones que hiciera de dichos temas nuestro pintor, puede relacionarse con su estilo. ${ }^{134}$

Por otro lado, una línea de investigación que ahora se nos abre es la de la posible colaboración entre los diferentes miembros de esta familia, más fácil de entender entre Pedro Ramírez, el viejo, y su hijo Laureano, en tanto que

I32. Rogelio Ruiz Gomar, "La Profesa”, M onografías de Arte Sacro, núm. I, M éxico, Comisión N acional de Arte Sacro, 1978, p. 8.

I33. Pintura novohispana. M useo N acional del Virreinato, M éxico, Asociación de Amigos del M useo N acional del Virreinato, I992, t. I, PI/oris, p. I2I.

I34. Pintura novohispana. M useo N acional del Virreinato, M éxico, Asociación de Amigos del M useo N acional del V irreinato, 1994, t. II, primera parte, PI/0239, p. 56. 
éste siguió los pasos y el oficio de aquél, pero igualmente factible entre los dos Pedro Ramírez, especialmente en aquellos trabajos contratados por el padre en que, por incluir pinturas, la participación del hijo se antoja más que lógica.

En esta situación estaría el retablo para la iglesia del Convento de Santa Clara, cuya hechura contrató el padre en febrero de 1660 por 9 mil pesos de oro común. En el banco o predella se menciona "un tablero de pincel, donde ha de llevar seis doctores de la I glesia o seis patriarcas [fundadores de órdenes], o lo que mejor pareciere y se pidiere". Para los intercolumnios del primer cuerpo se especifican lienzos de pincel "de la vida de santa Clara", amén de que en las puertas - al parecer se habla de las puertas del sagrario- " "ha de llevar las pinturas como se pidieren, así de tamaño como de alto". En el segundo cuerpo del retablo se habla de "otros dos lienzos de pincel de la vida de la santa... " Finalmente, para el remate se preveía la existencia de otros dos lienzos de la vida de la santa y, en la calle del medio, "un Santo Cristo, de pintura, con la Virgen, y san Juan y la M agdalena, y dos ángeles con sus cálices que estén recibiendo la sangre de las manos del Santo C risto... "I35

D esafortunadamente nada se dice en el contrato sobre el artista que habría de ocuparse de las pinturas. En él simplemente se expresa que "todo ello y dicha pintura [ha de ser] a satisfacción del dicho convento y religiosas de él y demás personas que por él se nombrasen"; y aunque más adelante se reitera, específicamente sobre las pinturas, que han de ser "del maestro que se eligiere por parte del dicho convento", es de suponer que Pedro Ramírez, el viejo, pudo influir en el ánimo de los demandantes para que la elección recayese en su propio hijo, aludiendo incluso a la conveniencia de que así podría tener un control total en la ejecución, tanto por lo que respecta a la cuestión del salario para el pintor, como de los materiales, dimensiones y tiempos de hechura.

D os inconvenientes se podrían ofrecer en la hipótesis de la posible colaboración entre el padre y los hijos en este trabajo en particular: el primero, la edad, ya que para entonces Pedro contaba con 22 años y Laureano con apenas los 20; y, el segundo, que para esos años quizá Pedro Ramírez, el joven, aún estaba avecindado en Puebla. Pero como la posibilidad no se puede descartar del todo, convendría retener la breve referencia que el cronista francis-

135. Archivo General de N otarías de la Ciudad de M éxico, notaría 633 (Juan de Salas), I659; citado por Efraín Castro M orales, op. cit., pp. I2-I3. 
DOI: http://dx.doi.org/10.22201/iie.18703062e.2000.77.1948

I08

ROGELIO RUIZ GOMAR

cano fray Agustín de Vetancourt nos dejó sobre ese retablo, y en particular de su sagrario, del que dice que tenía como puertas tablas en las que estaban "de pincel, la imagen de N uestra Señora en una, y la del Arcángel en la otra" (acaso una Anunciación). Y añade que cubriendo los relicarios estaban unas pinturas que giraban para descubrir las reliquias cuando la ocasión lo pedía, y que ahí estaban representadas "Ias nueve festividades de la Virgen". ${ }^{136}$

Para el mismo templo de Santa Clara, solemnemente consagrado el 22 de octubre de I66I - dato que nos ayuda a fechar el retablo anterior-, Pedro Ramírez padre contrató en enero de i662, y por dos mil pesos de oro común, la hechura del retablo que adornaría el altar del entierro de los herederos de Andrés Arias Tenorio, patrono de la iglesia; retablo que, ubicado en uno de los brazos del crucero, enfrente de la tribuna, contendría "diez lienzos de pintura", más "cuatro tableros" en el banco, con "la pintura que se le pidiere". 137

0 tro proyecto en el que perfectamente se pudo dar la colaboración entre padre e hijo fue el conocido túmulo que se erigió en la Catedral de M éxico para las honras fúnebres que los días 23 y 24 de julio de 1666 se celebraron por Felipe IV, y en cuya elaboración participaron I5o artistas dirigidos por Pedro Ramírez, el viejo, habida cuenta de que también en este monumento se consignan varias pinturas. Así, en la base o zoclo cuadrado de ocho pies de altura "se distribuyeron diez y seis lienzos de pincel, dos [pares] en cada uno [de los cuatro lados], divididos con pilastras de cantería, tan a lo natural, que era necesaria la experiencia del tacto para desengaño de los ojos, que miraban relieves sus lisuras". Asimismo, sobre el arquitrabe y friso del primer cuerpo "corría de pincel un lazo compartiéndose en él huesos cruzados y calaveras coronadas", por tres de las fachadas, pues en la del frente, o principal, estaba "una inscripción latina, alusiva al monarca, en campo blanco con caracteres negros". Y vale la pena destacar lo que se dice respecto a la cubierta de ese primer cuerpo, en la que "formó el pincel un cielo artesonado con fondos de jaspe y lacerías de bronce; tan en su lugar las sombras, tan ajustadas a la perspectiva sus disminuciones hasta rematar en una piña de relieve dorada, que con las apariencias de hundido desmentía todas las realidades de llano". De

136. Teatro mexicano..., M éxico, i698; tratado cuarto, capítulo I, parágrafo II, pp. ıо7-ıо; citado por Efraín Castro M orales, op. cit., p. I4. R efiriéndose a Pedro Ramírez padre, Vetancourt dice "cuyo nombre en su fama tiene adquirido tan singular aplauso", y le califica de "maestro de maestros del siglo que le goza".

137. Citado por Efraín Castro M orales, op. cit., p. i4. 
igual manera, se asienta que el cielo del segundo cuerpo "era de la misma obra y perfección que el del primero". En la relación que sobre las honras al monarca hizo Isidro de Sariñana, se ofrece una descripción minuciosa de la pira e incluye los versos y los i6 grabados que reproducían las pinturas que sirvieron para adornar los emblemas o jeroglíficos del túmulo. ${ }^{138} \mathrm{La}$ idea de que las pinturas que lució este túmulo debieron salir del pincel de Pedro Ramírez el mozo no parece descabellada; al menos así lo piensan también Guillermo Tovar de Teresa y Jaime Cuadriello. ${ }^{139}$

Pero he aquí que también Pedro Ramírez el viejo fue autor del túmulo que para la misma ocasión se levantó en el crucero del templo de Santo D omingo de la ciudad de M éxico, a solicitud del Santo Tribunal de la Inquisición, y cuyo programa, dispuesto por los jesuitas Francisco U ribe y Antonio $N$ úñez de M iranda, establecía paralelismo entre el monarca y N uma Pompilio. Este proyecto comprendió, además del adorno de trece esculturas, ocho pinturas en el zócalo (dos por cada lado), en las que Felipe IV era representado como el rey romano protector de los oficios, constructor de templos, etc. ${ }^{140}$ Para la ejecución de dichas pinturas también pudo solicitar la participación de Pedro Ramírez, hijo.

Sin poder afirmar nada, pues, podemos convenir al menos que resulta bastante plausible el que Pedro Ramírez de Contreras hubiese intervenido en los ambiciosos y complejos proyectos contratados por el padre, elaborando las pinturas que, de acuerdo con los programas enunciados, en ellos se requerían.

C aso diferente es el relativo a la construcción del retablo mayor de la iglesia de San Francisco de M éxico, contratado por Pedro Ramírez, el viejo, en

138. Llanto de 0 ccidente en el ocaso del más claro Sol delasEspañas, M éxico, I666, citado por G uillermo Tovar de Teresa, Bibliografía novohispana de arte. Primera parte, M éxico, Fondo de Cultura Económica, 1988, pp. 200-204.

139. Guillermo T ovar de Teresa, op. cit., p. 203, y Jaime C uadriello, "Los jeroglíficos de la N ueva España”, en Juegos de ingenio y agudeza. La pintura emblemática de la N ueva España, M éxico, Consejo N acional para la Cultura y las Artes, M useo N acional de Arte, 1994, p. 9I. Empero, cabe señalar que mientras para el primero la proposición sonaba lógica, pues extrañamente aún estaba en la creencia de que el maestro escultor y el maestro pintor eran un solo artista, el segundo, ya consciente de que se trata de dos artistas, padre e hijo, abiertamente propone que las pinturas las pudo hacer el hijo.

I40. Francisco U ribe y Antonio N úñez, H onorario túmulo,... , citado por G uillermo Tovar de Teresa, op. cit., pp. 194-200. 
DOI: http://dx.doi.org/10.22201/iie.18703062e.2000.77.1948

IIO

ROGELIO RUIZ GOMAR

julio de i662, y que habría de ser dorado y jaspeado, "imitando el Tecali", de nueve calles, cuatro de pintura y cinco de escultura. En este proyecto parece no haber precisado de la ayuda de su hijo, habida cuenta de que aquí se acordó conservar los tableros con pinturas del retablo anterior, hechos por el "afamado Basilio", según dejó constancia de ello el propio Vetancourt. ${ }^{\mathrm{I} I}$

Del mismo modo, habrá que estar atentos a la posible participación del Pedro Ramírez, pintor, en las obras ejecutadas por su hermano Laureano, por más que en este caso no parece haber sido tan importante, a juzgar por el tipo de obras realizadas por Laureano y las fechas en que las llevó a cabo. Sólo futuras investigaciones vendrán a confirmar si existió o no dicha colaboración. Por ahora me concreto a recoger algunas noticias en torno al quehacer artístico de Laureano.

En septiembre de i 667 concertó la hechura del monumento de cuaresma del Convento de Regina Coeli, obra en la que su padre aparece como fiador.

En enero de i668 aceptó como aprendiz a M artín de Asencio, hijo del mestizo $M$ artín de la $C$ ruz, oficial de sastre, por cinco años.

En enero de i675 concertó la fábrica del monumento de cuaresma para la iglesia del Convento de la Encarnación.

En 1679 se comprometió a realizar la "renovación" del retablo de Jesús M aría - erigido hacia i625 y cuyas pinturas habían sido realizadas por Luis Juárez- ${ }^{142}$ sustituyendo las partes apolilladas, modernizándolo, revistiendo con talla nueva las columnas y construyendo un nuevo sagrario. Es interesante consignar que, por encontrarse el estofado de las esculturas en buen estado, Laureano se ocupó sólo de la renovación del mismo, y que, en lo referente a las pinturas, se decidió a conservarlas por ser tan hermosas, ciñéndose únicamente a eliminarles la polilla a las tablas de los soportes y a retocar sus enmarcamientos. Sólo en el caso del cuadro de La Asunción, en el centro del tercer cuerpo, se asentó que si se le hallara irreparable debería hacerse nuevo. En lo tocante a dos escudos que contenían las armas reales, se asentó que "se han de echar dos tableros nuevos de pincel... más pequeños", y lo mismo

I4I. O p. cit., tratado segundo, capítulo 3, parágrafo 43, p. 34; el "afamado Basilio" no es otro que el tardomanierista Basilio de Salazar. En relación con este artista, activo en el segundo tercio de esa centuria, véase Xavier M oyssén, "Basilio de Salazar, un pintor del siglo XVII", en Anales del I nstituto de Investigaciones Estéticas, vol. XIII, núm. 46, M éxico, 1976.

I42. Vid. N uria M aría Salazar, "El convento de Jesús M aría de la ciudad de M éxico. H istoria artística 1577-I860" (tesis para obtener el grado de Licenciado en H istoria del Arte por la U niversidad Iberoamericana), M éxico, 1986. 
DOI: http://dx.doi.org/10.22201/iie.18703062e.2000.77.1948

NUEVAS NOTICIAS SOBRE LOS RAMÍREZ

para la representación en óvalo del Padre Eterno que iría en el remate, de la que se dice "ha de ser por cuenta del dicho maestro". Es fácil suponer que para estas obras de pintura Laureano hubiese pedido la ayuda a su hermano; pero poco es lo que éste pudo haber hecho, pues, como se recordará, Pedro Ramírez de C ontreras murió a mediados de ese año.

En i678 Laureano se había comprometido a hacer el retablo de san Francisco Javier para la iglesia jesuita de San Pedro y San Pablo, por 6500 pesos. Q uizá había espacio para pinturas en él, pero lo cierto es que para este trabajo no se pudo dar la colaboración entre los hermanos, pues por alguna razón la obra no se llevó a cabo, y no sería hasta i682 cuando se hizo, pero para entonces ya Pedro había muerto. ${ }^{143}$

Y, aunque también resulta extemporánea, no podemos dejar de mencionar la otra gran obra en que intervino Laureano: el retablo mayor del Templo de los Betlemitas. El contrato para su ejecución está datado el in de octubre de i685. Laureano cobraría 3600 pesos de oro, y debería entregarlo debidamente terminado en poco más de un año, antes del 3 de noviembre de I686, para la fiesta de san Francisco Javier, a quien estaba dedicado. Empero, como ya sabemos, Laureano falleció el 23 de octubre de ese mismo año de i 686 y no pudo concluirlo, pues por el diario de Antonio de Robles sabemos que no se estrenó hasta el 28 de diciembre de i703. Sea como fuere, lo cierto es que dicho retablo no contenía pinturas, tal y como se aprecia en el delicioso y estupendo exvoto que hiciera el bachiller Carlos de Villalpando, y que se conserva en el M useo $\mathrm{N}$ acional del Virreinato. ${ }^{\text {I44 }}$

I43. N o deja de ser interesante la noticia de que al centro del segundo cuerpo de dicho retablo se colocaría una pintura en tabla que representaba a "San Ponciano", la cual, según se dice en el nuevo contrato, Laureano tenía en su casa. ¿Sería de su propiedad? En tal caso podría ser obra del hermano. N o obstante, del mismo modo cabe pensar que dicha pintura era una obra que pertenecía a los jesuitas, y que Laureano tenía bajo su custodia en tanto procedía a armar correctamente el retablo. Sin embargo, dada la poca veneración que dicho santo tuvo en la N ueva España, se antoja pensar que dicha obra no es otra que la conocida tabla con el $M$ artirio de san Ponciano de Baltasar de Echave $O$ rio (que después de haberse guardado en la Pinacoteca Virreinal de San D iego, de la ciudad de M éxico, hoy en día está en el M useo N acional de Arte), suposición a la que se opone el que el cuadro de Echave, al decir de José Bernardo Couto, se compró a mediados del siglo pasado a un particular para las galerías de la A cademia de San Carlos.

I44. V éase G onzalo O bregón, "N otas sobre una obra del bachiller C arlos de Villalpando", en Retablo barroco a la memoria de Francisco de la M aza, M éxico, Universidad N acional Autónoma de M éxico, Instituto de Investigaciones Estéticas, 1974. 
DOI: http://dx.doi.org/10.22201/iie.18703062e.2000.77.1948

II2

ROGELIO RUIZ GOMAR

En condición similar está la noticia concerniente al retablo que Laureano se comprometió a hacer en abril del mismo año de 1685 , por medio de su oficial Luis Rodríguez, para la parroquia de la Villa de Llerena de Sombrerete, en Zacatecas. ${ }^{145}$

Por último, no podemos dejar de mencionar que se consigna el nombre de Laureano entre los de los artistas que fueron convocados a hacer la inspección y dar dictamen en relación con la renovación del Cristo de Ixmiquilpan. ${ }^{146}$

Como se ha podido ver, la familia de "los Ramírez" comportó, pese a las naturales desavenencias ocasionales, una gran unidad a lo largo del siglo XVII y aun en las primeras décadas de la centuria siguiente, unidad que se fue construyendo y afianzando mediante fuertes lazos internos, propios de toda relación entre padres e hijos, entre hermanos, entre tíos y sobrinos, abuelos y nietos. Así, hemos podido constatar que, mientras unos aparecen como padrinos en los bautizos o como testigos en las bodas, también se aprovecha la existencia de sacerdotes en la familia, y no pocas veces atestiguamos que éstos presidían diversas ceremonias. Por otra parte, también tuvimos oportunidad de constatar que en ningún momento los R amírez desdeñaron el relacionarse con muy diversos miembros de su comunidad, en la que encontramos lo mismo escribanos que comerciantes, canónigos que funcionarios, frailes que artistas de distintas disciplinas.

No se me escapa que la mayor parte de las noticias recogidas poco o nada tienen que ver con la actuación y producción artística de cada uno de los integrantes de esta singular familia novohispana. Pese a ello, si me he animado a recogerlas y darlas a conocer, es porque estoy convencido de que no sólo arrojan algo de luz sobre sus biografías - y es que no se debe perder de vista que, desde su condición humana, mucho nos conforta el poder ver que nacen, crecen, se casan, tienen hijos y mueren - , sino que, como entes sociales, también se han relacionado con muy diversa gente de las comunidades en que se movieron mediante vínculos de trabajo, pero también de esencia religiosa, que permiten inferir un trato más cercano que la simple amistad al

145. Archivo General de N otarías de la Ciudad de M éxico, notaría núm. i99 a cargo de Juan Díaz de Ribera; apud. Silvia Bravo y Raquel Pineda, Catálogos de D ocumentos de Arte, 7. Archivo General de N otarías de la Ciudad de M éxico. II, ª ed., M éxico, U niversidad N acional Autónoma de M éxico, Instituto de Investigaciones Estéticas, I996; ficha or42, p. I59.

I46. Guillermo Tovar de T eresa, Bibliografía novohispana..., t. I, p. 32I. 
aceptar, por ejemplo, ser testigos en bodas o apadrinar en bautizos a los hijos de otros. Si he optado por retener los nombres de muchos de ellos, como padrinos o testigos, pese a que la mayor parte de esos nombres no significaba nada para mí, es porque estoy convencido de que acaso puedan ser más adelante identificados por otros estudiosos como personajes que desempeñaron una función importante en la sociedad novohispana de la época, ya como miembros de la comunidad artística, ya relacionados con comerciantes o mineros, ya como funcionarios de corporaciones de la época, etc., y que, a partir de dichos lazos, se pudiera deducir con más cimientos y mayor claridad la importancia de la familia.

Y aunque gracias a la información que se ha ido reuniendo sobre ellos ya difícilmente se pudiera decir que se trata de artistas poco conocidos, creo que falta trabajar con más profundidad la actuación de cada uno de ellos, bien en forma conjunta, bien por separado, para al canzar a aquilatar en su verdadera dimensión la importancia artística así de los dos Pedro Ramírez como de Laureano Ramírez de Contreras. Cada uno de ellos bien merecería un estudio monográfico.

Como dejé apuntado líneas atrás, un punto inexplorado aún es el de los trabajos que pudieran haber sido realizados en equipo, a partir del taller que tenía Pedro Ramírez, el viejo, y que había heredado de su padre Diego Ramírez. La transmisión del oficio de padres a hijos, tan frecuente en el mundo artesanal de la N ueva España, y favorecida por el sistema laboral existente que descansaba en la estructura gremial, explica que Laureano hubiese seguido los pasos de su progenitor, y que éste, a su vez, hubiese continuado el oficio de su propio padre, quien acaso también lo había recibido del suyo. Lo que se antoja un tanto diferente y que de hecho viene a enriquecer a este taller de corte familiar es la inclusión en él de un maestro pintor, quien pudo fungir como un complemento perfecto en los proyectos que incorporaran trabajos de esa disciplina artística. La estrecha colaboración entre padre e hijos se antoja, pues, bastante probable, cuanto más que, como hemos visto, con frecuencia los proyectos contratados por Pedro Ramírez, el viejo, incluían pinturas. Lo mismo cabría esperar entre nuestro pintor y Laureano.

Convencido de la importancia que han alcanzado "Ios Ramírez" en la historia de las manifestaciones artísticas de la N ueva España, he reunido aquí noticias dispersas o hasta ahora desconocidas, con la esperanza de que sean útiles en la tarea que deberá venir a continuación, que es la de elaborar estudios monográficos de cada uno de ellos. Así, por más que D iego Angulo ha- 
ya expresado que Pedro Ramírez, el pintor, es un artista contemporáneo de José Juárez, pero de segunda fila, ${ }^{\mathrm{I} 77}$ confío en que un estudio atento de su producción nos habrá de entregar a una de las figuras más sugestivas de esta etapa. Como hemos visto, su obra conocida no es muy abundante, pero viene a ser, junto con la de Arteaga, José Juárez y Baltasar de Echave Rioja, una de las cartas fuertes de esa modalidad hasta ahora denominada claroscurista, pero que en realidad debe entenderse como de vena naturalista, y que, como se ha dicho, se introdujo hacia mediados del siglo XvII en la N ueva España.

Tiene razón Jorge Alberto $M$ anrique cuando señala que, sin perder el gusto por los contrastes lumínicos, Ramírez derivó hacia una pintura más luminosa, más rica en composición; esto es, más barroca, especialmente más barroca a la mexicana, al superponer al toque "zurbaranesco" que empezaba a extenderse la influencia de Rubens, cuya presencia, por medio de grabados, se empieza a sentir también por estas fechas en el medio novohispano. ${ }^{148}$

Así, agrega, en su evolución podemos distinguir ese ir de Zurbarán a Rubens hasta desembocar en el estilo mexicano del tercer tercio del siglo XVII, que daría nacimiento a la pintura del grupo de Villalpando y Correa: a ese tipo de pintura que tiene mucho de Zurbarán, mucho de Rubens, asimilado posteriormente, y mucho también de una tradición local, difícil de definir, que arranca desde manieristas como Echave 0 rio y Luis Juárez. ${ }^{149}$

Y concluye afirmando que la importancia de Pedro Ramírez resalta cuando nos percatamos de que, junto con Echave Rioja, se trata de uno de los pintores que ayudaron a forjar el estilo mexicano del último tercio del siglo XVII, ese estilo que Toussaint ha considerado como el más propiamente diferenciable de nuestra pintura colonial. ${ }^{\text {I5o }}$ is

I47. O p. cit., t. II, p. $4 \mathrm{I} 6$.

I48. 0 p. cit., p. 76.

I49. I bidem, p. 77. Esta tradición - dice- no se refiere sólo a ciertas convenciones iconográficas, sino a elementos más propiamente pictóricos, como es ese sentimiento de la delicadeza, ese gusto por la riqueza y el barroquismo pródigo de formas, pero al mismo tiempo tímido en sus concepciones generales, ese medirse en las expresiones dolorosas (lo que no sucede, por ejemplo, en la escultura).

I50. I bidem. 
DOI: http://dx.doi.org/10.22201/iie.18703062e.2000.77.1948

NUEVAS NOTICIAS SOBRE LOS RAMÍREZ

Genealogía de D iego Ramírez

Primer matrimonio

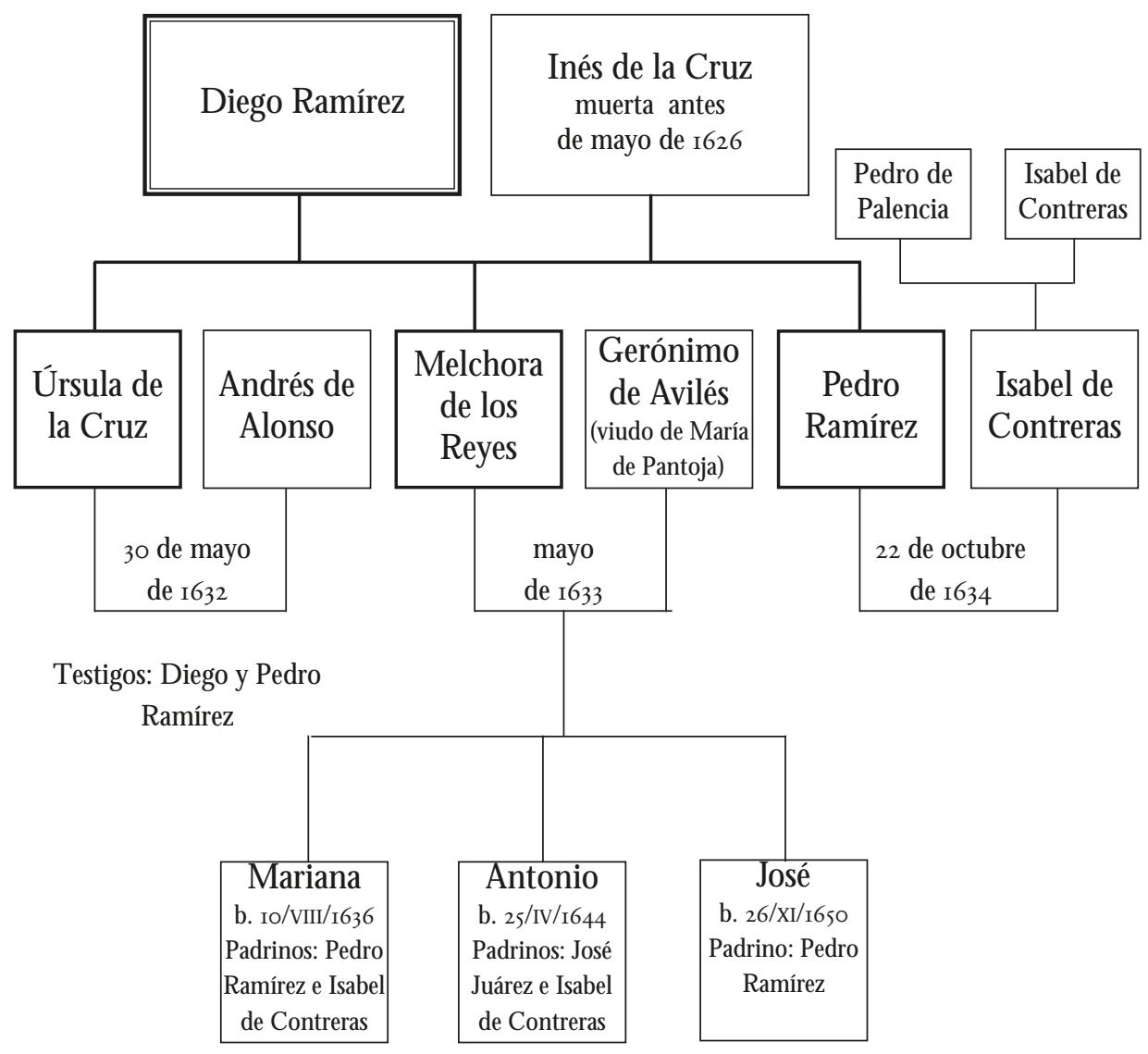


DOI: http://dx.doi.org/10.22201/iie.18703062e.2000.77.1948

II6

ROGELIO RUIZ GOMAR

Genealogía de D iego Ramírez

Segundo matrimonio

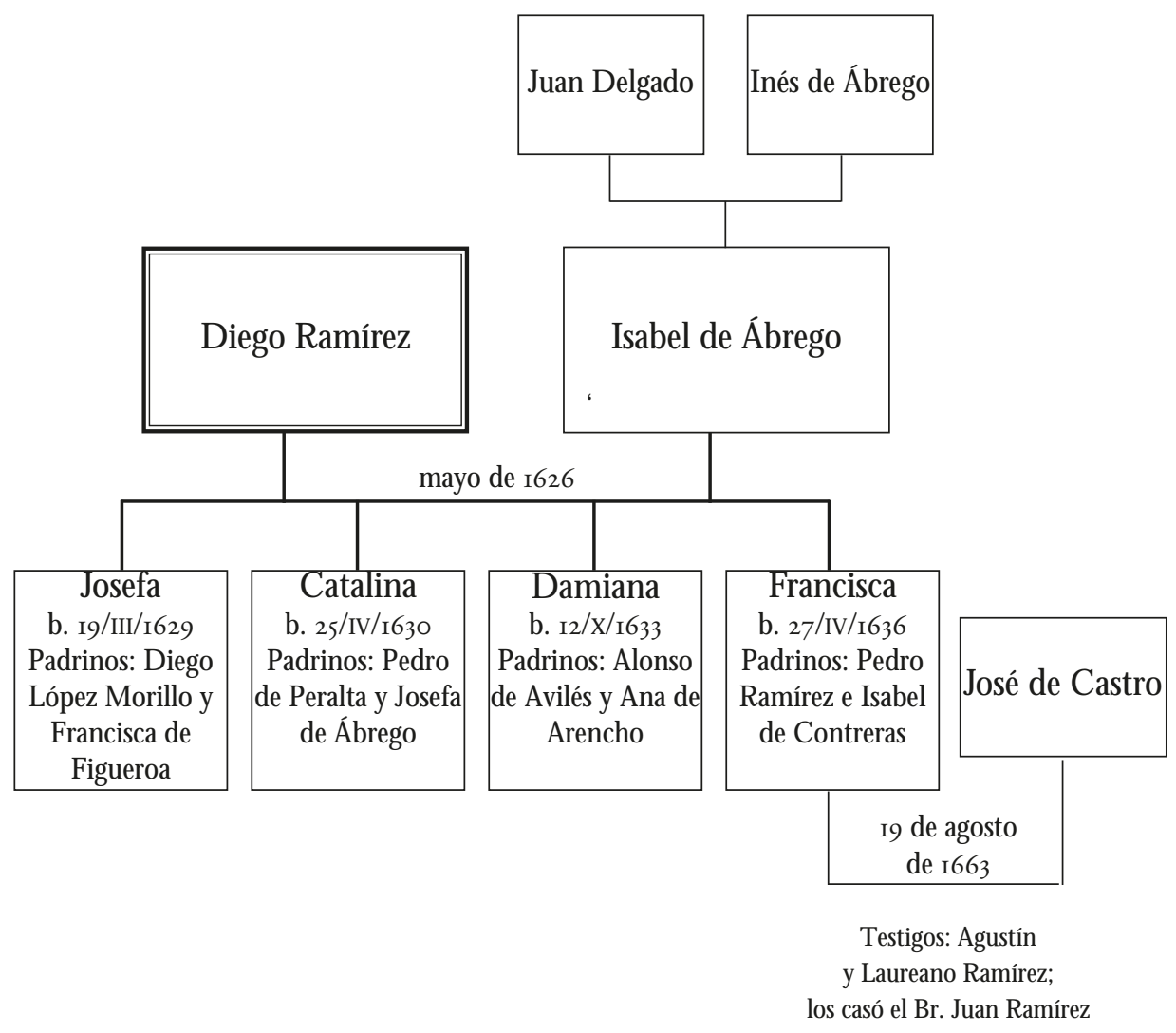


DOI: http://dx.doi.org/10.22201/iie.18703062e.2000.77.1948

NUEVAS NOTICIAS SOBRE LOS RAMÍREZ

Genealogía de Pedro Ramírez, el viejo

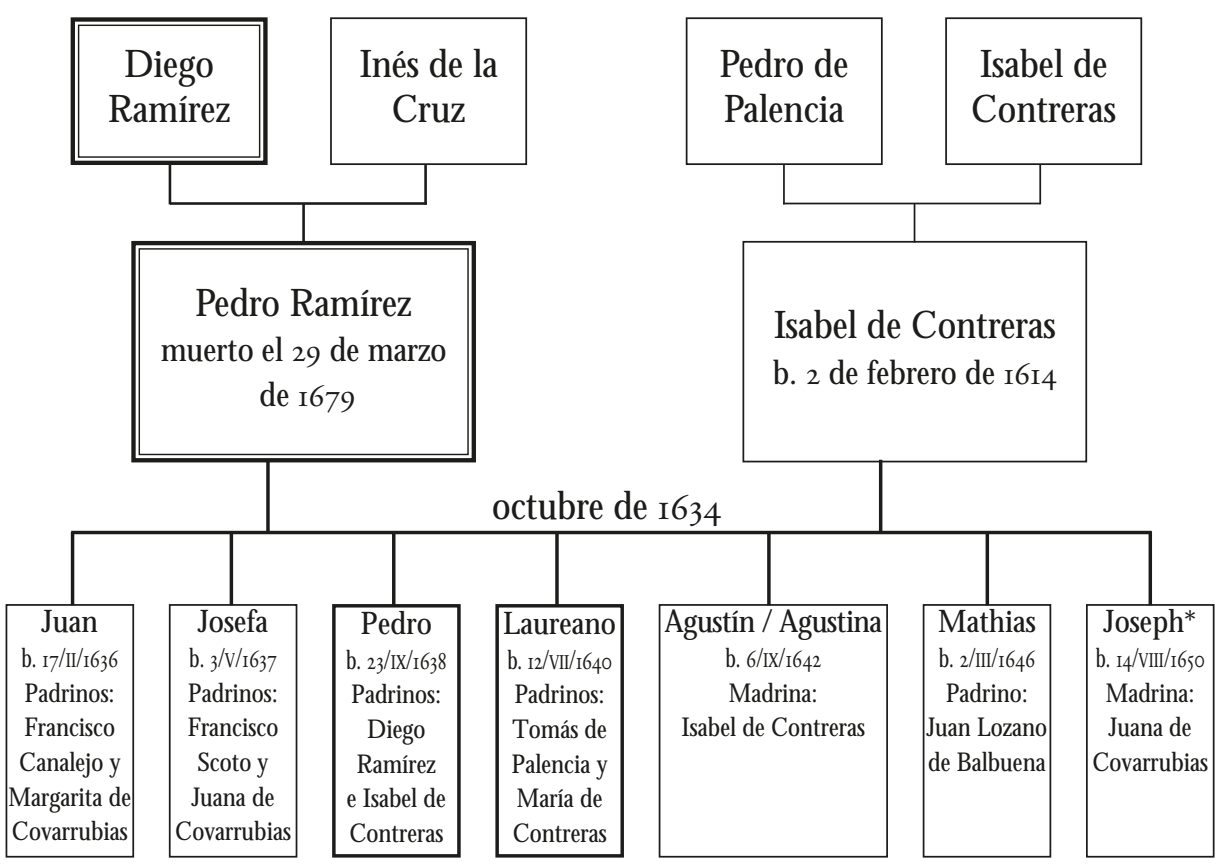

* Se casó con doña M aría M achado y Sierra (julio de I676), viuda del capitán Pedro de Andrada. 
DOI: http://dx.doi.org/10.22201/iie.18703062e.2000.77.1948

II8

ROGELIO RUIZ GOMAR

G enealogía de Pedro Ramírez de C ontreras

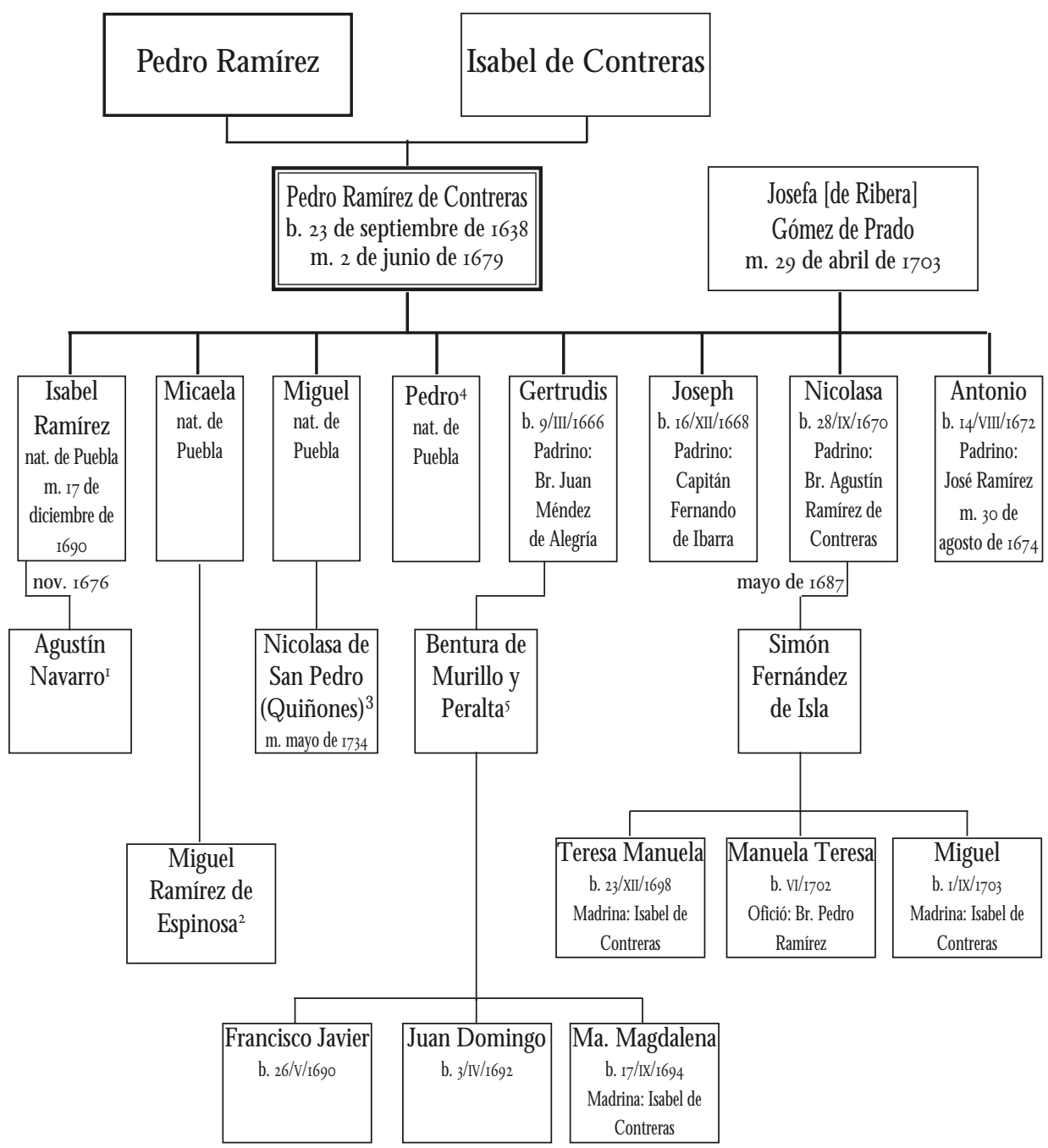

I $\mathrm{H}$ ijo de Juan $\mathrm{N}$ avarro y M aría $\mathrm{H}$ idalgo. Al enviudar, en diciembre de I69o, volvió a casarse con M aría de las $\mathrm{N}$ ieves (viuda de Francisco de Alcalá).

2 H ijo de D omingo Ramírez de Espinosa y M aría C abañas; el enlace fue en noviembre de i679.

$3 \mathrm{H}$ ija de T omás de San Pedro el sabel de Q uiñones. El enlace fue en junio de 1680.

4 Ya de edad adulta se le designará como bachiller Pedro Ramírez de Contreras.

$5 \mathrm{H}$ ijo del capitán Francisco M urillo y doña Inés de Peralta; el enlace fue en abril de I684. 
DOI: http://dx.doi.org/10.22201/iie.18703062e.2000.77.1948

NUEVAS NOTICIAS SOBRE LOS RAMÍREZ

II9

\section{G eneal ogía de Laureano Ramírez de Contreras \\ Primer matrimonio}

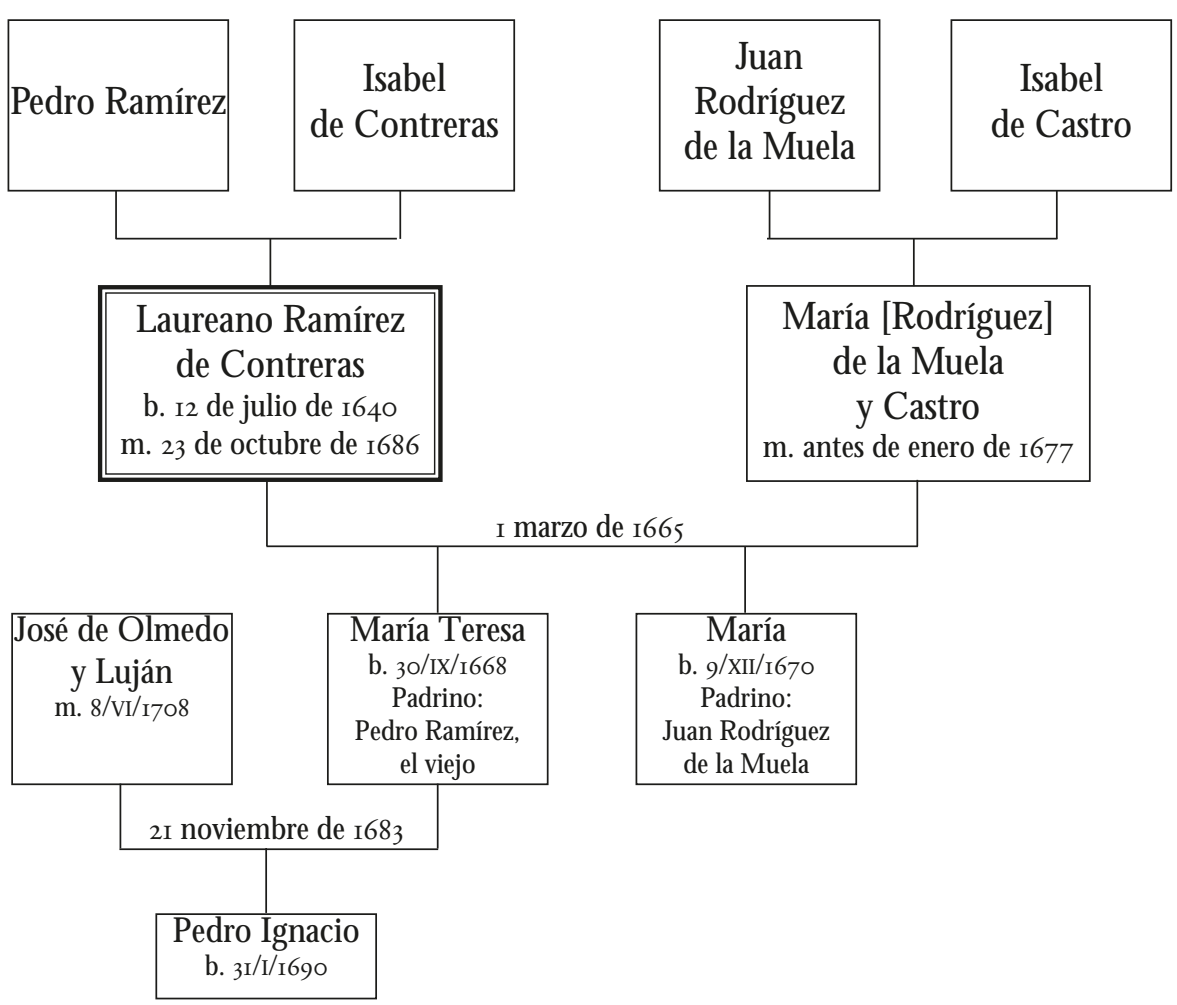


DOI: http://dx.doi.org/10.22201/iie.18703062e.2000.77.1948

I2O

ROGELIO RUIZ GOMAR

Geneal ogía de Laureano Ramírez de Contreras

Segundo matrimonio

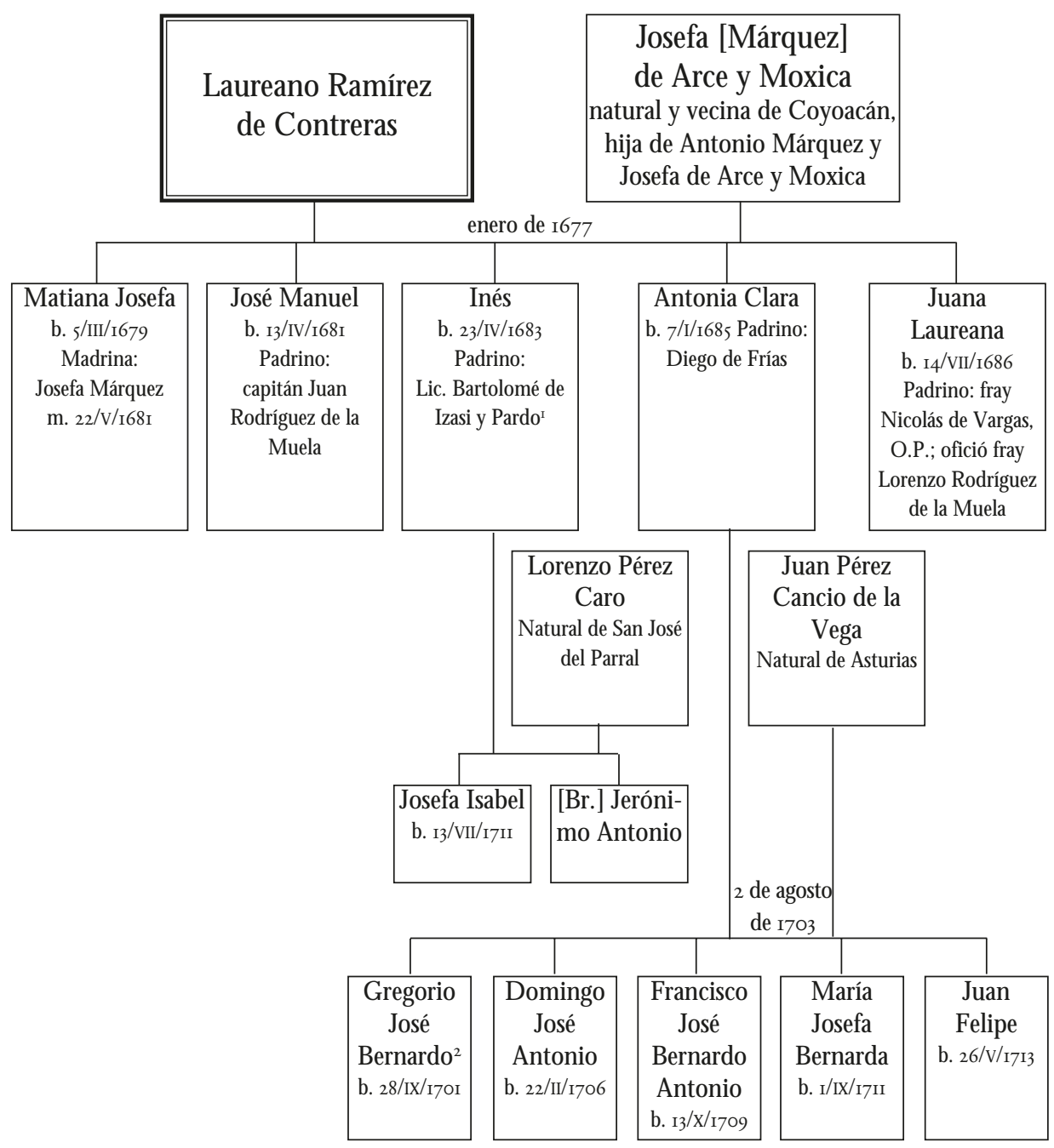

${ }^{\mathrm{I}} \mathrm{C}$ ura de Teoloyucan.

2 Expuesto y luego reconocido. Se casó (8 de julio de ${ }^{1719}$ ) con doña M aría de los D olores Fernández de Villaseñor y Salgado, vecina y natural de San Juan del Río, Q uerétaro. H ijo de este matrimonio fue el célebre doctor Gregorio Pérez Cancio. 
DOI: http://dx.doi.org/10.22201/iie.18703062e.2000.77.1948

NUEVAS NOTICIAS SOBRE LOS RAMÍREZ

O tras familias

a.

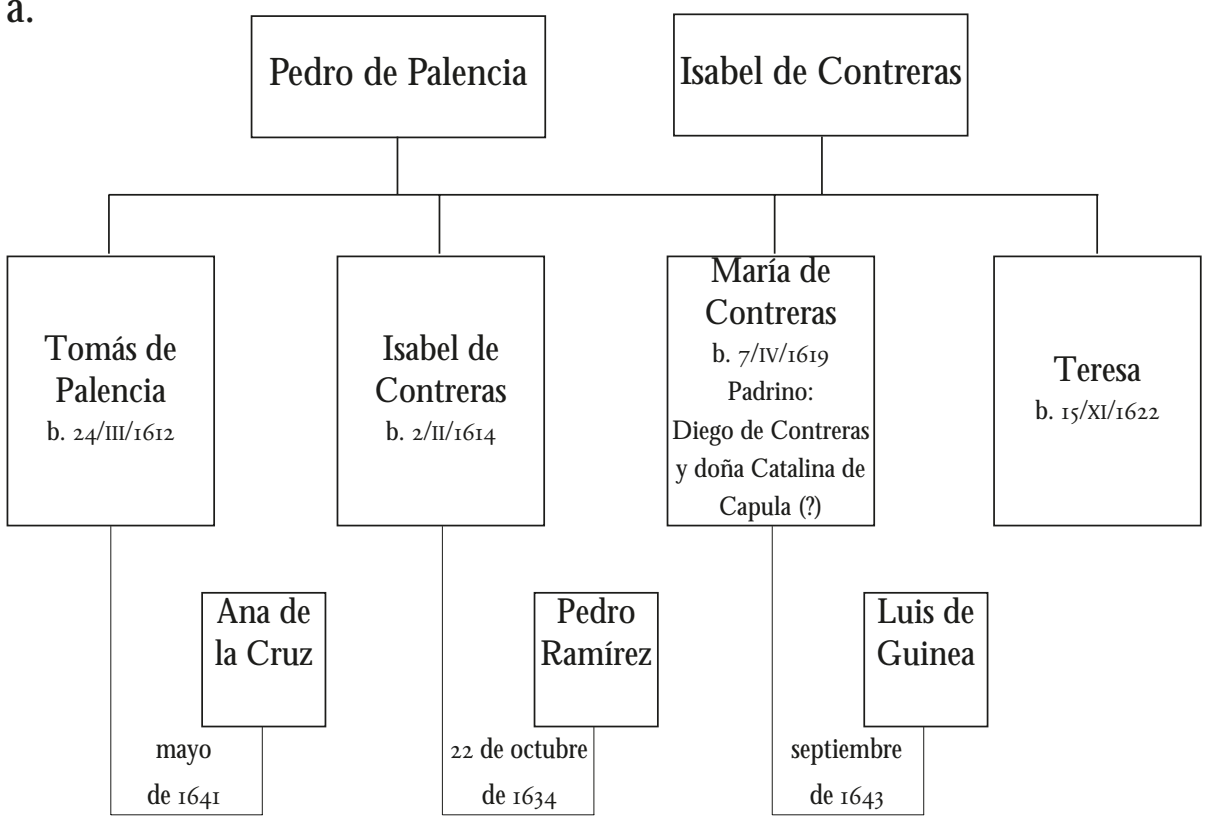

b.

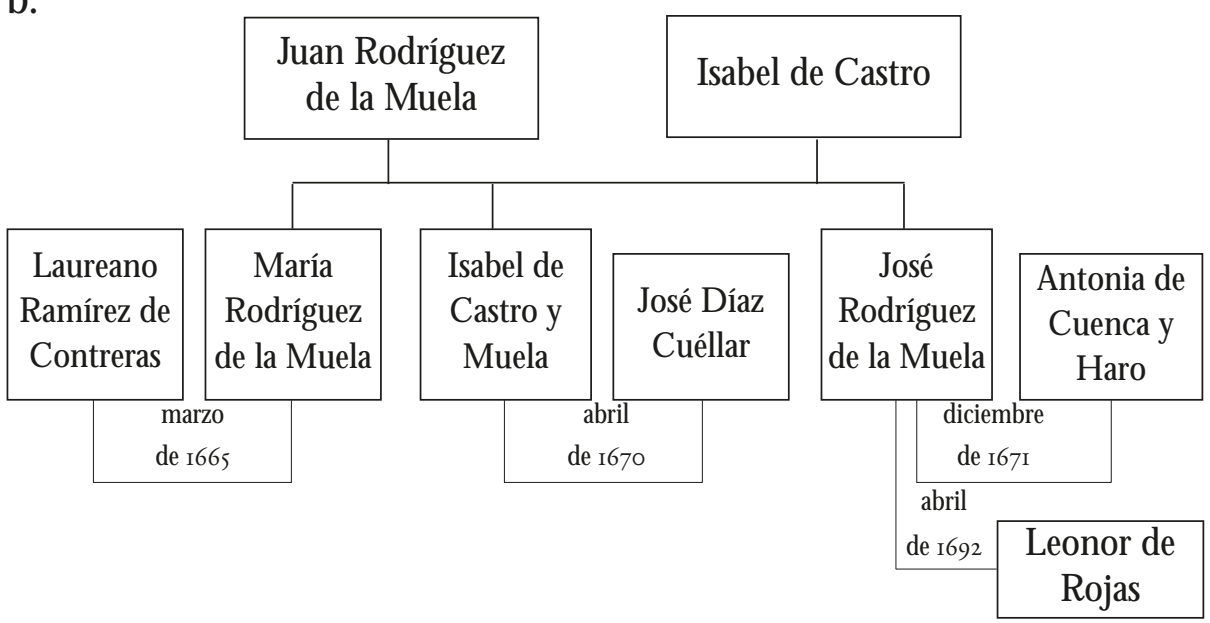

